\title{
Göç-Güvenlik Bağlantısını Yeniden Düşünmek: Eleștirel Güvenlik Yaklaşımları, Özgürleşme ve Türkiye'deki Suriyeli Mülteciler
}

Rethinking the Migration-Security Nexus: Critical Security Approaches, Emancipation, and Syrian Refugees in Turkey

\section{Mine Nur KÜÇÜK}

Dr. Öğr. Üyesi, Yeditepe Üniversitesi, Siyaset Bilimi ve Uluslararası İlişkiler Bölümü

\section{Bu makaleye atıf için}

Mine Nur Küçük, "Göç-Güvenlik Bağlantısını Yeniden Düşünmek: Eleștirel Güvenlik Yaklaşımları, Özgürleşme ve Türkiye'deki Suriyeli Mülteciler”, Uluslararası İişkiler, Cilt 18, Say1 69, 2021, s. 3-28, DOI: $\underline{10.33458 / \text { uidergisi.777329 }}$

Makaleye Erişim İçin: https://dx.doi.org/10.33458/uidergisi.777329

Makale Gönderim: 9 Aralık 2019

Son Düzeltme: 25 Temmuz 2020

İnternet Yayım: 31 Temmuz 2020

Basım Tarihi: 17 Nisan 2021

\section{Uluslararası İlişkiler Konseyi Derneği | Uluslararası İlişkiler}

E-Posta: bilgi@uidergisi.com.tr

Bu makalenin tüm hakları Uluslararası İişkiler Konseyi Derneği’ne aittir. Önceden yazılı izin almadan hiçbir iletişim, kopyalama ya da yayın sistemi kullanılarak yeniden yayımlanamaz, çoğaltılamaz, dağıtılamaz, satılamaz veya herhangi bir şekilde kamunun ücretli/ücretsiz kullanımına sunulamaz. Akademik amaçlı alıntılar bu kuralın dışındadır. Yazıda belirtilen fikirler yalnızca yazarına/yazarlarına aittir. UİK Derneğini, editörleri ve diğer yazarları bağlamaz. 


\title{
Göç-Güvenlik Bağlantısını Yeniden Düşünmek: Eleştirel Güvenlik Yaklaşımları, Özgürleşme ve Türkiye'deki Suriyeli Mülteciler*
}

\author{
Mine Nur KÜÇÜK \\ Dr. Öğr. Üyesi, Yeditepe Üniversitesi, Siyaset Bilimi ve Uluslararası İlişkiler Bölümü, İstanbul \\ E-posta:mine.kucuk@yeditepe.edu.tr
}

\section{ÖZET}

Soğuk Savaş’ın bitişinden itibaren eleştirel güvenlik yaklaşımlarının güvenlik çalışmalarına önemli etkileri olmuştur. Göç ve güvenlik arasındaki ilişki bu literatürdeki en önemli konulardan birisidir. Bu makale eleştirel güvenlik çalışmalarındaki yaklaşımlarından biri olan Aberystwyth ekolünün göç-güvenlik ilişkisini anlamak için sunacağı özgün katkıları tartışmayı amaçlamaktadır. Bu katkılar, makalede Türkiye'deki Suriyeli mülteciler örneği üzerinden incelenmiştir. Makale ayrıca Aberystwyth ekolüne göre göç-güvenlik bağlantısı bağlamında literatürde daha çok ele alınan Kopenhag ve Paris ekollerinin bu bağlantıya nasıl yaklaştığını irdelemektedir. Makalede bu ekollerin literatüre sundukları farklı kuramsal ve ampirik katkılar, onların kısıtları ve bu kısıtların ötesine Aberystwyth ekolünün nasıl geçtiği de ele alınmaktadır.

Anahtar Kelimeler: Eleştirel Güvenlik Yaklaşımları, Göç, Aberystwyth Ekolü, Suriyeli Mülteciler, Türkiye

\section{Rethinking the Migration-Security Nexus: Critical Security Approaches, Emancipation, and Syrian Refugees in Turkey}

\begin{abstract}
Following the end of the Cold War, critical security approaches have made significant inroads into the security studies scholarship. The relationship between migration and security has been one of the most significant issues in this literature. This article aims to discuss the novel contributions of one of the approaches in critical security studies, namely Aberystwyth school, in understanding the migration-security nexus. These contributions are examined with reference to the example of Syrian refugees in Turkey. The article also scrutinizes Copenhagen and Paris schools, which have been employed more than the Aberystwyth school concerning the migration-security nexus. It elaborates on the distinct theoretical and empirical contributions of these schools, their limitations, and how Aberystwyth school goes beyond these limitations.
\end{abstract}

Keywords: Critical Security Approaches, Migration, Aberystwyth School, Syrian Refugees, Turkey

\footnotetext{
Bu makalenin gelişimindeki değerli katkıları için Hakan Sipahioğlu'na, Neslihan Dikmen-Alsancak’a ve Uluslararası İlişkiler dergisi hakemlerine teşekkür ederim.
} 


\section{Giriş}

İkinci Dünya Savaşı́nın sona ermesini takiben ayrı bir çalışma alanı olarak ortaya çıkmasından bu yana güvenlik çalışmalarına çoğunlukla askeri meselelere odaklanan ve devletlerin hayatta kalmasıyla ilgilenen geleneksel teoriler hâkim olmuştur. Özellikle Soğuk Savaş sonrasında bu geleneksel anlayış eleştirel güvenlik yaklaşımları tarafından sorgulanmaya başlanmıştır. Aralarındaki farklara rağmen eleştirel yaklaşımların amacı geleneksel kuramlardaki "evrensel ve soyut güvenlik tanımlarını” problemleştirerek ve tehlikelerin önceden verili olmaktan ziyade toplumsal olarak inşa edilmiş olduklarının altını çizerek $^{2}$ güvenlik kavramının anlamını sorgulamak olmuştur. Bu yaklaşımlar neticesinde güvenliğin anlamı genişletilmiş ve güvenliğin referans nesnesi ve aktörleri derinleştirilmiştir. ${ }^{3}$ Güvenliğin anlamının genişletilmesiyle askeri alan dışındaki diğer sektörler de ele alınmaya başlamış, güvenliğin derinleştirilmesi ile "kimin güvenliği” ve "güvenliği kim sağlayabilir" sorularına devletin ötesinde cevapların verilmesi mümkün olmuştur.

Tüm bu eleştirel güvenlik tartışmaları içerisinde göç önemli bir konu haline gelmiştir. Bu literatüre göre göç, "Soğuk Savaşın sona ermesine bağlı jeopolitik yer değiştirmeler” ve "küreselleşmeyle bağlantılı daha geniş sosyal ve politik kaymalar” gibi gelişmelerin neticesi olarak bir güvenlik konusu olarak ortaya çıkmıştır. ${ }^{4}$ Örneğin, "göç-güvenlik bağlantısını”’ merkez ülkeler ${ }^{6}$ bağlamında ele alan araştırmacılar her ne kadar bu bağlantının Soğuk Savaş öncesinde de kurulduğunun altını çizseler de, ${ }^{7}$ bu bağlantının gelişmesinin asıl Soğuk Savaş sonrasına tekabül ettiğini belirtirler. Bourbeau, 1990'larda Yugoslavya Savaşı ve Ruanda soykırımı gibi gelişmeler neticesinde ortaya çıkan "mülteci krizi” ve 11 Eylül saldırılarının merkez ülkelerde göç-güvenlik bağlantısını güçlendiren birtakım söylem ve pratiklere yol açtığını belirtmiştir. ${ }^{8}$ Yine son dönemde Suriye İç Savaşının sebep olduğu insan hareketliliği bu bağlantının devam ettirilmesinde önemli bir rol oynamaktadır. Fakat eleştirel güvenlik çalışmaları göçün yukarıda bahsedilen gelişmelerin "doğal” bir sonucu olarak güvenlik ile ilişkilendirilmediğini, bunun aksine merkez ülkelerdeki aktörlerin bu olayları nasıl yorumladıkları ve bu olaylar karşısında nasıl davrandıklarının bir sonucu olarak göçün bir güvenlik sorunu olarak çerçevelendiğinin altını çizmiştir.

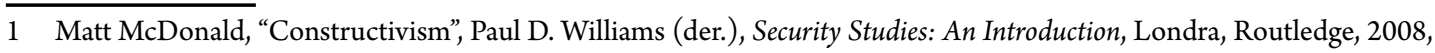
s. 61.

2 Jef Huysmans, "Agency and the Politics of Protection: Implications for Security Studies", Jef Huysmans, Andrew Dobson ve Raia Prokhovnik (der.), The Politics of Protection: Sites of Insecurity and Political Agency, Oxon, Routledge, 2006, s. 4.

3 Keith Krause ve Michael C. Williams, "Broadening the Agenda of Security Studies: Politics and Methods", Mershon International Studies Review, Cilt 40, No 2, 1996, s. 230.

4 Jef Huysmans ve Vicki Squire, “Migration and Security”, Myriam Dunn Cavelty ve Victor Mauer (der.), The Routledge Handbook of Security Studies, Oxon, Routledge, 2009, s. 169.

5 William Walters, "Migration and Security", J. Peter Burgess (der.), The Routledge Handbook of New Security Studies, Londra, Routledge, 2010, s. 218.

6 Makale boyunca "merkez", "Kuzey” ve "Küresel Kuzey” terimleri yer değiștirilerek "Batı Avrupa ve Kuzey Amerika" anlamında kullanılacaktır. "Merkez dışı", "Güney” ve "Küresel Güney” terimleri ise, dünyanın "daha az etki sahibi" "baskın olmayan" ya da "ayrıcalıklı olmayan" yerleri anlamında kullanılacaktır. Sırasıyla bkz. Pınar Bilgin, "Security in the Arab World and Turkey: Differently Different”, Arlene B. Tickner ve David L. Blaney (der.), Thinking International Relations Differently, Oxon, Routledge, 2012, s.43 ve Ole Waever ve Arlene B. Tickner, "Introduction: Geocultural Epistemologies", Arlene B. Tickner ve Ole Waever (der.), International Relations Scholarship around the World, Londra, Routledge, 2009, s. 1.

7 Andrew Geddes, The Politics of Migration and Immigration in Europe, Londra, Sage Publications, 2003, s. 40.

8 Philippe Bourbeau, The Securitization of Migration: A Study of Movement and Order, Londra, Routledge, 2011, s. 99-101. 
Bu makale göç-güvenlik ilişkisini eleştirel güvenlik çalışmaları çerçevesinde ele almaktadır. Makalenin amacı göç-güvenlik ilişkisi bağlamında literatürde görece daha az ele alınmış olan Aberystwyth ekolünün önerdiği çerçevenin bu ilişkiyi anlamada ne gibi katkılar sunabileceğini tartışmaktır. Makale özellikle iki katkının altını çizmektedir. Öncelikle Aberystwyth ekolü bireyleri hem güvenliğin referans nesnesi olarak ele almakta hem de güvenlik alanında farklı aktörlerin etkin olduklarına dikkat çekmektedir. Bu ekol ayrıca "güvenliği siyasileştirerek" göç alanında yaşanan güvensizliklerin ötesine nasıl geçebileceğimizi düşünmek için bizlere yeni alanlar açmaktadır. İkinci olarak Aberystwyth ekolünün geliştirdiği çerçeve merkez dışı bağlamlarda (diğer bir deyişle Güney-Güney göçüyle ilişkili olarak) yaşanan güvensizlikleri anlamada ve bunlara çözüm bulmada önemli katkılar sunmaktadır. Makale bu iki katkıyı Türkiye'deki Suriyeli mülteciler örneği üzerinden incelemektedir. Makalenin bu örneğe odaklanmasının sebebi Suriye İç Savaşı neticesinde zorla yerlerinden edilen Suriyelilerin dünyadaki en büyük mülteci grubunu oluşturması ve Türkiye'nin de an itibariyle dünyada en çok mülteciye ev sahipliği yapan ülke olmasıdır. ${ }^{9}$

Makale Aberystwyth ekolünün bu özgün katkılarını vurgulamak için göç-güvenlik bağlantısını analiz ederken sıklıkla kullanılan Kopenhag ve Paris ekollerinin bu bağlantıyı kuramsal ve ampirik anlamda nasıl ele aldıklarını ve bu ekollerin kısıtlarını da kapsamlı bir şekilde tartışmaktadır. Bunu yaparak makale hem bu kısıtların ötesine Aberystwyth ekolünün nasıl geçtiğini göstermeyi, hem de eleştirel güvenlik ve göç alanlarında Türkçe yazına bir katkı sunmayı hedeflemektedir. ${ }^{10}$ Şüphesiz eleştirel güvenlik çalışmaları salt bu ekollerden oluşmamakta, bu literatürde feminist, postkolonyal, yeşil teori gibi farklı yaklaşımlar da bulunmaktadır. ${ }^{11}$ Dolayısıyla bu çalışma tüm eleştirel güvenlik yaklaşımlarını kapsama iddiasında değildir. Fakat makalede ele alınan ekoller, Browning ve McDonald'ın deyimiyle, eleştirel güvenlik çalışmalarının "kök örnekleri” (archetypal examples) olarak kabul edilebilir. ${ }^{12}$ Dolayısıyla, makalenin bu üç ekole odaklanmasının nedeni, Waever'ın da belirttiği üzere, bu ekollerin içinde ve arasındaki tartışmaların eleştirel güvenlik alanındaki farklı (örneğin inşacı, post-yapısalcı, Eleştirel, feminist ${ }^{13}$ gibi) kavramsal anlayışların anlaşılması açısından oldukça verimli olmasıdır. ${ }^{14}$

9 https://www.unhcr.org/ph/figures-at-a-glance (Erişim Tarihi 20 Temmuz 2020).

10 Türkçe yazında genellikle bu ekollerin önerdiği çerçeveler göç-güvenlik bağlantısı hakkındaki ampirik çalışmalarda kullanılmıştır (bazı örnekler için bkz. Nazif Mandacı ve Gökay Özerim, "Uluslararası Göçlerin Bir Güvenlik Konusuna Dönüşümü: Avrupa’da Radikal Sağ Partiler ve Göçün Güvenlikleştirilmesi”, Uluslararası İlişkiler, Cilt 10, No 39, 2013, s. 105-130; Gökay Özerim, "Avrupa'da Göç Politikalarının Ulusüstüleşmesi ve Bir Güvenlik Konusuna Dönüşümü: Avrupa Göç Tarihinde Yeni bir Dönem mi?”, Ege Stratejik Araştırmalar Dergisi, Cilt 5, No 1, 2014, s. 11-48; Sabiha Nur Meç, “Göçün Güvenlikleştirilmesi: Almanya'da Aşırı Sağ Parti AfG’nin Yükselişi ve Suriyeli Mülteci Krizi”, ViraVerita E-Dergisi, No 8, 2018, s. 123-150.) Göç-güvenlik alanında salt kuramsal tartışmalara odaklanan ve özellikle bu üç okula karşılaştırmalı olarak bakan Türkçe yayınlar ise görece sınırlı kalmıştır. Rumelili ve Karadağ’n 2017 senesinde Toplum ve Bilim Dergisinde yayınladıkları makale buna bir istisnadır. Fakat bu makalede de yazarlar eleştirel güvenlik ekollerinden ziyade, bu literatürdeki ana kavramlara odaklanmışlardır. Bkz. Bahar Rumelili ve Sibel Karadağ, "Göç ve Güvenlik: Eleştirel Yaklaşımlar”, Toplum ve Bilim, No 140, 2017, s. 69-92.

11 Eleştirel güvenlik çalışmaları literatürüne genel bir bakış için bkz. Laura J. Shepherd (der.), Critical Approaches to Security: An Introduction to Theories and Methods, Oxon, Routledge, 2013.

12 Christopher S. Browning ve Matt McDonald, "The Future of Critical security studies: Ethics and the Politics of Security”, European Journal of International Relations, Cilt 19, No 2, 2011, s. 235.

13 Örneğin kimi yazarlar Feminist yazında başat bir öneme sahip olan "toplumsal cinsiyet” kavramının Aberystwyth ekolünün önerdiği "özgürleşme olarak güvenlik” çerçevesinin ayrılmaz bir parçası olduğunun altını çizmektedir. Böyle bir çalışma için bkz. Soumita Basu, "Security as Emancipation: a Feminist Perspective", J. Ann Tickner ve Laura Sjoberg (der.), Feminism and International Relations: Conversations about the Past, Present and Future, Oxon, Routledge, 2011, 98-114.

14 Ole Waever, "Aberystwyth, Paris, Copenhagen: the Europeanness of New 'Schools' of Security Theory in an American Field”, Arlene B. Tickner ve David L. Blaney (der.), Thinking International Relations Differently, Oxon, Routledge, 2012, s. 48. Ayrica bkz. C.A.S.E. Collective, "Critical Approaches to Security in Europe: A Networked Manifesto", Security 
Makalenin eleştirel güvenlik çalışmaları bağlamında özellikle göç-güvenlik bağlantısını irdelenmesinin önemi ise iç savaşlar, ekonomik krizler, doğal afetler gibi gelişmeler neticesinde son yıllarda dünya çapındaki uluslararası göçmenlerin sayısındaki hılı $\operatorname{artışs~}^{15}$ göz önünde bulundurulduğunda ortaya çıkmaktadır. Örneğin, göç konusu dünyanın farklı yerlerindeki karar alıcılar için, çoğunlukla güvenlik prizmasından bakılan, ana konulardan biri haline gelmiştir. Ayrıca, Uluslararası İlişkiler (Uİ) ve diğer disiplinlerde de göç-güvenlik ilişkisine dair literatür gelişmeye devam etmektedir. ${ }^{16}$

Bu makale üç bölümden oluşmaktadır. Makalenin ilk bölümünde göç-güvenlik bağlantısını çalışırken sıklıkla başvurulan Kopenhag ve Paris ekollerinin bu bağlantıya nasıl yaklaştıkları tartışılacaktır. Bu bölümde bu iki ekolün kısıtları, bu yaklaşımlara özellikle Aberystwyth ekolü tarafından getirilen eleştiriler üzerinden irdelenecektir. İkinci bölümdeyse makale bu iki ekole kıyasla göç-güvenlik ilişkisi bağlamında daha az ele alınmış olan Aberystwyth ekolünün ana argümanlarına değinerek, ekolün bu ilişkiyi analiz ederken önerebileceği çerçevenin önemine dikkat çekecektir. Bunu yaparken diğer iki ekolün kısıtlarını Aberystwyth ekolünün nasıl aştı̆̆ı tartışılacaktır. Makalenin üçüncü bölümünde ise bu ekolün önerdiği çerçevenin katkıları Türkiye'deki Suriyeli mülteciler örneği üzerinden incelenecektir.

\section{Göç-Güvenlik Bağlantısı: Kopenhag ve Paris Ekollerinin Katkı ve Kısıtları}

\section{Kopenhag Ekolü: Söylemsel Yaklaşım}

Kopenhag ekolü 1980'lerde “Kopenhag Barış Araştırmaları Enstitüsü” bünyesinde yer alan "Avrupa güvenliği” isimli araştırma grubu içerisinden çıkmıştır. ${ }^{17}$ Ekol özellikle literatüre sunduğu "güvenlikleştirme” (securitization) kavramı ile bilinmektedir. Güvenlikleştirme bir "söz edimidir" (speech act), bir konunun "varoluşsal bir tehdit” olarak söylemsel inşasıdır. ${ }^{18}$ Bir başka deyişle, konular dil vasıtasıyla güvenlik meselesi haline getirilirler. "Varoluşsal bir tehdit" olarak özneler arasında inşa edilen bu konular ele alınırken "olağandışı önlemlerin" kullanılmaları da böylece mümkün olur. ${ }^{19} \mathrm{Bu}$ yolla güvenlikleştirilmiş bir konu "normal politika" (tartışma ve müzakerenin mümkün olduğu yavaş işleyen dönüşümler) alanından "istisnai” (tartışma ve müzakerenin değersizleştirildiği hızlı işleyen süreçleri kapsayan) alana taşınmış olur. ${ }^{20} \mathrm{Bu}$ anlamda Kopenhag ekolü güvenliği "istisnalar politikası” çerçevesinde ele alır. ${ }^{21}$

Dialogue, Cilt 37, No 4, 2006, s. 443-487.

15 Birleşmiş Milletler'e göre 2000 yılında 173 milyon olan göçmen sayısı 2017 yılında 258 milyona ulaşmıştır. Bkz. UN, International Migration Report 2017: Highlights, New York, UN, 2017.

16 Örneğin bkz. Philippe Bourbeau (der.), Handbook on Migration and Security, Cheltentam, Edward Elgar Publishing, 2017.

17 Waever, “Aberystwyth, Paris, Copenhagen: the Europeanness of New 'Schools”, s. 66.

18 Barry Buzan et al., Security: A New Frameworkfor Analysis, Boulder, Lynne Rienner Pub, 1998; Ole Waever, "Securitization and Desecuritization”, Ronnie D. Lipschutz (der.), On Security, New York, Columbia University Press, 1995, s. 46-87.

19 Ole Waever, "Aberystwyth, Paris, Copenhagen: New Schools in Security Theory and their Origins between Core and Periphery", Paper presented at the annual meeting of the International Studies Association, Montreal, 17-20 March 2004, s. 8.

20 Jef Huysmans, "Minding Exceptions: The Politics of Insecurity and Liberal Democracy”, Contemporary Political Theory, Cilt 3, No 3, 2004, s. 321-341.

21 Thomas Diez ve Jef Huysmans, “The Socio-Political Effects of Securitising Free Movement: The Case of 9/11," ESRC End of Award Report, RES-223-23-0055, Swindon, ESRC, 2007. 
Bu açıdan bakıldığında Kopenhag ekolünün güvenlik kavramına olumsuz bir yaklaşımı olduğu söylenebilir. Örneğin Waever güvenliği "muhafazakâr bir konsept" olarak tanımlarken ihtiyacımız olan şeyin daha az "güvenlik konuşması" olduğunu dile getirir. ${ }^{22}$ Ona göre güvenlikleştirme bir konunun "normal politika" içerisinde ele alınamadığı bir "başarısızlı̆̆ı" temsil eder. ${ }^{23}$ Bu negatif anlayış ekolün gündeminde başka bir kavramın doğmasına neden olmuştur: "güvenlik-dışılaştırma" (desecuritization). Güvenlik-dışılaştırma bir konuyu güvenlikleştirilmiş bir alandan "normal politika” alanına taşımak anlamına gelmektedir. ${ }^{24}$

Güvenlikleştirme ve güvenlik-dışılaştırma kavramları dışında bu ekolün literatüre yaptığı bir diğer katkı ise farklı "güvenlik sektörleri” üzerine yoğunlaşmasından kaynaklanmaktadır. Buna göre Kopenhag ekolü sadece devletlerin askeri güvenlikleri ile ilgilenmez. Askeri güvenliğe ek olarak ekol; ekonomik, çevresel, politik ve toplumsal olmak üzere, güvenlikleştirme sürecinin konusu olabilecek dört farklı sektörü de analiz eder. ${ }^{25}$

Kopenhag ekolü göç konusunu, özellikle de "göçün güvenlikleştirilmesi” konusunu toplumsal sektör içerisinde ele alır. "Toplumsal güvenlik” bir olay ya da konunun aktörler tarafından kendilerinin "bir topluluk olarak hayatta kalmalarına tehdit olarak" kabul edilmesi ile ilgilidir. ${ }^{26} \mathrm{Bu}$ güvenlik, bir topluluğun bir sorunu kendi kolektif "kimliğine" yönelik bir tehdit olarak tanımladığında ortaya çıkar. Bu bağlamda toplumsal güvenlik bireysel değil, “'biz’ kimliğini korumak için yapılan eylemleri” içeren kolektif bir olgudur. ${ }^{27}$ Yani toplumsal güvenliğin referans nesneleri ("korunması gereken” olarak addedilen nesneler) toplum ya da toplumsal kimliktir. Göç konusu "X halkı Y halkının akınıyla istila ediliyor veya seyreltiliyor; $\mathrm{X}$ topluluğu eskisi gibi olmayacak, çünkü toplum diğerlerinden oluşacak; $\mathrm{X}$ kimliği nüfusun kompozisyonundaki kaymayla değişime uğruyor” gibi söz edimleriyle güvenlik konusu haline getirilmektedir. ${ }^{28}$ Karyotis' in belirttiği üzere bu tarzdaki göçün toplumsal kültür ya da kimliğe bir "tehdit” olarak görülmesi Avrupa'daki göç söylemlerinin genel bir özelliğini oluşturmaktadır:

"Belirli bir toplum, onu diğer toplumlardan eşsiz ve farklı kılan şeyleri kaybetme korkusuyla, kimliğine yönelik tehditlerin yabancılardan kaynaklandığı algısına sahip olabilir. Bu güvensizlik, genellikle göçmen grupların yüksek doğum oranları tarafından beslenen, göçmen varlı̆̆ının sonunda ev sahibi ülkenin etnik, kültürel, dini ve dilsel kompozisyonunu değiş̧tirebileceği korkusundan kaynaklanmaktadır."29

Toplumsal güvenliğin göçün güvenlikleştirilmesi konusundaki merkeziliğini anlamak için bakabileceğimiz bir örnek Swartz ve Karakatsanis'in 1990’larda Yunanistan üzerine yaptıkları bir çalışmadır. ${ }^{30}$ Yazarlara göre Yunanlılar, Yunanca konuşmayı, "Yunan tarzı bir hayat tarzına” sahip olmayı

22 Waever, "Securitization and Desecuritization", s. 56.

23 Waever, "Aberystwyth, Paris, Copenhagen: New Schools in Security Theory."

24 Waever, "Securitization and Desecuritization"; Buzan et al., Security: A New Framework for Analysis, s. 4.

25 Buzan et al., Security: A New Framework for Analysis, s. 7-8. Güvenliğin farklı sektörde incelenmesi gerektiğinin altını çizen erken dönem bir çalışma için bkz. Barry Buzan, People, States and Fear: An Agenda for International Security Studies in the Post-Cold War Era, Boulder, Lynne Rienner Pub, 1991.

26 Ibid., s. 119.

27 Ibid., s. 120.

28 Ibid., s. 121.

29 Georgios Karyotis, "European Migration Policy in the Aftermath of September 11", Innovation: The European Journal of Social Science Research, Cilt 20, No 1, 2007, s. 9.

30 Jonathan Swarts ve Neovi M. Karakatsanis, “The Securitization of Migration: Greece in the 1990s”, Journal of Balkan and Near Eastern Studies, Cilt 14, No 1, 2012, s. 33-51. 
ve Hıristiyan olmayı göçmenlerin ülkelerine yerleşmelerine izin vermek için önemli "kriterler" olarak değerlendirmişlerdir. Yunanistan'daki göçmenlerin bu "kriterlere" çoğunlukla uymadıkları göz önünde bulundurulduğunda, bu göçmenlerin toplum tarafından bir "tehdit" olarak anlaşıldıkları ortaya çıkmaktadır. ${ }^{31}$ Yazarlara göre bu anlayış aynı zamanda göçmenleri Yunanlıların güvenliklerini tehdit eden "suçlular" olarak resmedilmeleri ile de pekiştirilmektedir.

Peki bu güvenlikleştirmeyi gerçekleştiren aktörler kimlerdir? Kopenhag ekolü bu soruya toplumsal aktörler cevabını vermektedir. Bu aktörler devlet başkanları, siyasetçiler, ya da medya gibi güç sahibi kişi ya da kurumlardan oluşabilir. Göç alanındaki en önemli güvenlikleştirici aktörlerden birisi sağ politikacılar ya da siyasi partilerdir. Örneğin, Thorleifsson Macaristan vakasını inceleyerek bu ülkedeki aşırı sağ partilerin zorunlu göçü güvenlikleştiren en önemli aktörler olduklarını vurgulamıştır. ${ }^{32}$ Yazara göre bu partiler göçmenleri "milli kültür, refah, güvenlik ve hatta bir bütün olarak Hıristiyan medeniyetine tehdit teşkil eden”, “Macar ulusunun düşmanları” olarak sunmaktadırlar. ${ }^{33}$ Bunu yaparken, örneğin, Macaristan'daki ilan panoları kullanılmakta ve buralarda Suriye, Afganistan, Irak gibi ülkelerden gelen mültecilerin Macaristan'ı “tehdit ettikleri” iddiaları yer bulmaktadır. ${ }^{34}$

Göçün güvenlikleştirilmesinin sebebiyet verdiği bu tip dışlayıcı söylem ve politikaların altını çizen Kopenhag ekolü, göçün güvenlik-dışılaştırılmasının gerekliliğini vurgular. ${ }^{35}$ Böylelikle göçmenlerin bir güvenlik tehdidi olduğuna dair algının yanlışlığı ortaya konabilir, biz/onlar ayrımı ve göç ile güvenlik arasındaki bağlantı problemleştirilebilir. ${ }^{36}$ Fakat bunu söyledikten sonra altı çizilmesi gereken bir husus vardır: Güvenlik-dışlaştırma Kopenhag ekolünün analitik çerçevesi içerisinde görece az geliştirilmiş bir kavram olmuştur. ${ }^{37}$ Bazı akademisyenlere göre ise (ilerleyen bölümlerde de değinileceği gibi) güvenlik-dışılaştırma "normal politikalar" nedeniyle güvensizleşmiş bireylerin daha da güçsüz kılınması sonucunu doğurabilir. ${ }^{38}$

Kopenhag ekolünün eleştirel güvenlik çalışmaları literatürüne katkıları çok önemli olmakla birlikte, bu ekole yine literatür içerisinden birçok eleştiri de yöneltilmiştir. Makalenin sorunsalı bağlamında burada bu eleştirilerden üçüne odaklanılacaktır. İlk eleştiri ekolün güvenlikleştirme kavramını bir söz edimi olarak tanımlamasına yöneliktir. Örneğin Hansen, Pakistan'daki namus cinayetleri örneğinden hareketle beyanatların salt söze dayalı iletişim unsurlarından oluşmadığını, aynı zamanda sözsel olmayan "beden" gibi unsurların da "konuşma" kapasitesine sahip olduğundan bahsederek Kopenhag ekolünü eleştirmiştir. ${ }^{39}$ Hansen bazı insanların güvensizliklerini diledikleri gibi dile geti-

31 Ibid., s. 39.

32 Cathrine Thorleifsson, "Disposable Strangers: Far-Right Securitization of Forced Migration in Hungary”, Social Anthropology, Cilt 25, No 3, 2017, s. 318-334.

33 Ibid., s. 319.

34 Ibid., s. 321-322.

35 Jef Huysmans, "Migrants as a Security Problem: Dangers of Securitizing Societal Issues", Robert Miles ve Dietrich Thranhardt (der.), Migration and European Integration: The Dynamics of Inclusion and Exclusion, Londra, Pinter, 1995, s. 53-72; Rens Van Munster, “The Desecuritization of Illegal Migration: The Case for a European Belonging Without Community", Paper presented at the PhD-seminar/EUROPA workshop, Department of Political Science and Public Management, University of Southern Denmark, Odense, 26 October, 2004.

36 Huysmans, "Migrants as a Security Problem".

37 Claudia Aradau, "Security and the Democratic Scene: Desecuritization and Emancipation”, Journal of International Relations and Development, Cilt 7, No 4, 2004, s. 388-413.

38 Ken Booth, Theory of World Security, Cambridge, Cambridge University Press, 2007, s. 168.

39 Lene Hansen, "The Little Mermaid's Silent Security Dilemma and the Absence of Gender in the Copenhagen School”, Millennium- Journal of International Studies, Cilt 29, No 2, 2000, s. 285-306. 
remediğinden bahsetmiş, bu kişilerin başka güvensizlikler yaşamamak için sessiz kaldıklarını ve bu sessizliğin bir strateji olarak kullanıldığını belirtmiştir. Bu eleştirilerle ilişkili olarak Aberystwyth ekolü söz edimlerinin Kopenhag ekolü için merkeziliğinin bu ekolün "elitist” bir odağa sahip olduğunu gösterdiğini belirtmektedir. Örneğin Booth bu ekolün merkezinde liderler, devletler ya da güç sahibi dinleyicilerin olduğunu ve bu anlamda söylem üretme gücünden yoksun kimselerin bu ekol tarafından göz ardı edildiğini belirtmiştir. ${ }^{40}$

Kopenhag ekolü tarafından ele alındığı biçimiyle güvenliğin referans nesneleri ve aktörleri de başka bir eleştiri noktası olmuştur. Örneğin Aberystwyth ekolünün kurucularından olan Wyn Jones bu ekolün "devlet merkezli bir ontolojisi” olduğunu dile getirerek bunun devlet dışındaki referans nesnelerinin görmezden gelinmesi sonucunu doğurduğunu belirtir. ${ }^{41} \mathrm{McDonald’a}$ göre bu ontolojinin sonuçlarından biri bireyleri, özellikle de marjinalize edilmiş ve sessiz kılınmış bireyleri, göz ardı etmek olmuştur. ${ }^{42}$ Diğer bir deyişle, Kopenhag ekolü politik elitlerin rolleri ve söylemlerinin üzerinde gereğinden fazla durmakta, bunu yaparken de göç-güvenlik ilişkisini farklı bir biçimde ele alan demokratik karşı anlatılara yeterince değinmemektedir. ${ }^{43}$

Kopenhag ekolüne getirilen diğer bir eleştiri ise ekolün merkez dışı bağlamlarla kurduğu ilişkideki kısıtlardır. Bu noktadan kastedilen bu ekolün çerçevesinin ampirik olarak merkez dışı bağlamları çalışan akademisyenler tarafından kullanılmamış olması değildir. ${ }^{44}$ Burada problemleştirilen nokta bu ekolün önerdiği anlayışlara (ki bu anlayışlar belirli merkez ülkelerde mevcut olan "liberal demokrasi" deneyimleri üzerinden gelişmiştir) evrensel muamelesi yapılmasıdır. Örneğin, Wilkinson, Kopenhag ekolünün çerçevesinin merkez dışı bir aktör olan Kırgızistan'da uygulanıp uygulanamayacağını sorguladığı makalesinde bunun mümkün olmadığını söyler. ${ }^{45}$ Yazara göre bunun nedenlerinden biri bu ekolün Avrupa'daki toplum ve devlet anlayışını evrensel olarak varsaymasıdır. ${ }^{46}$ Bilgin de Kopenhag ekolünün güvenlik-dışılaştırma kavramını zamandan ve mekândan bağımsız, evrensel normatif bir yol olarak sunmasını eleştirir. ${ }^{47}$ Yazar, Avrupa bağlamında başarılı olabilecek güvenlik-dışılaştırma süreçlerinin, dünyanın başka yerlerinde de benzer şekilde istenilen sonuçları doğurmayabileceği ihtimalini vurgulamaktadir.

Bu bölümü özetlemek gerekirse, Kopenhag ekolü güvenlikleştirme, güvenlik-dışılaştırma, kimlik, toplumsal güvenlik gibi kavramlar aracılığıyla literatüre göç-güvenlik bağlantısını anlamada önemli katkılar sunmaktadır. Fakat bu, bu ekolün kısıtları olmadığı anlamına gelmemektedir. Ekol, ön-

40 Booth, Theory of World Security, s. 166.

41 Richard Wyn Jones, Security, Strategy, and Critical Theory, Boulder, Lynne Rienner Pub., 1999, s. 104.

42 Matt McDonald, "Securitization and the Construction of Security", European Journal of International Relations, Cilt 14, No 4, 2008, s. 563-587.

43 Robert W. Glover, "The Theorist and the Practitioner: Linking the Securitization of Migration to Activist CounterNarratives", Geopolitics, History, and International Relations, Cilt 3, No 1, 2011, s. 77-102; Ali Bilgiç, Rethinking Security in the Age of Migration: Trust and Emancipation in Europe, Oxon, Routledge, 2013, s. 6-7.

44 Bazı örnekler için bkz. Juha, A. Vuori, "Illocutionary Logic and Strands of Securitization: Applying the Theory of Securitization to the Study of Non-Democratic Political Orders", European Journal of International Relations, Cilt 14, No 1, 2008, s. 65-99; Aslı Ilgit ve Audie Klotz, "How far does 'Societal Security' Travel? Securitization in South African Immigration Policies”, Security Dialogue, Cilt 45, No 2, 2014, s.137-155.

45 Claire Wilkinson, “The Copenhagen School on Tour in Kyrgyzstan: Is Securitization Theory Useable Outside Europe?”, Security Dialogue, Cilt 38, No 1, 2007, s. 5-25.

46 Ibid., s. 5.

47 Pınar Bilgin, “Making Turkey's Transformation Possible: Claiming Security-speak- not Desecuritization!”, Southeast European and Black Sea Studies, Cilt 7, No 4, 2007, s. 555-571. 
celikle söz edimine yaptığı vurgu nedeniyle farklı "konuşma biçimlerini”, Avustralya'daki mültecilerin dudaklarını dikmesi örneğinde olduğu gibi, ${ }^{48}$ göz ardı etmiştir. İkinci olarak, ekolün devlet merkezli ontolojisi özellikle göç gibi bireylerin çok çeşitli güvensizlikler yaşadığı ve devlet dışı aktörlerin bu güvensizlikleri giderme yolunda alternatif söylemler ürettiği bir alanda birçok eleştiriye maruz kalmıştır. Son olarak bu ekolün sunduğu anlayışlar temelde merkez aktörlerin deneyimleri üzerine inşa edilmişken, bunların evrensel geçerliliği olduğu varsayımının da Kopenhag ekolünün bir diğer kısıtlılığı olduğu belirtilmiştir.

\section{Paris Ekolü: Pratiğe Dayalı Yaklaşım}

Paris ekolünün kuramsal çerçevesi Michel Foucault gibi postyapısalcı düşünürlerin çalışmalarından etkilenerek oluşturulmuştur. Bu ekolün en önemli temsilcisi olarak kabul edilen Didier Bigo, Paris ekolünün güvenliğe yaklaşımını "Uluslararası Siyaset Sosyolojisi” olarak da isimlendirmiştir. ${ }^{49} \mathrm{Bu}$ isimlendirmenin arkasında yatan neden Paris ekolünün "uluslararası güvenliği” "ulusal güvenlikten” ayrı gören yaklaşımları problemli bulması ve bunun yerine bu iki alanın birbiriyle olan ilişkisinin ortaya koyulmasının gerekliliğini vurgulamasıdır. ${ }^{50} \mathrm{Bu}$ anlayış ekolün güvenlik yaklaşımının; sosyoloji, siyaset bilimi, kriminoloji, coğrafya, Uluslararası İlişkiler gibi farklı disiplinlerden beslenmesi sonucunu doğurmuştur.

Paris ekolünün eleştirel güvenlik literatürüne en önemli katkılarından birisi güvenlikleştirme kavramını yeniden tanımlamak olmuştur. Huysmans güvenlikleştirmeyi "Beceriler, uzman bilgisi, kurumsal rutinler ve tehlike söylemlerinin güvenlik ve özgürlük arasındaki ilişkiyi değiştirdiği çok boyutlu bir süreç" olarak tanımlamaktadır. ${ }^{51}$ Bu tanım şunu göstermektedir: Paris ekolüne göre güvenlikleştirme eylemi belirli bir söz edimiyle, zamanda bir an içerisinde gerçekleşmez. Güvenlikleştirme, belirli bir süreç içerisinde gerçekleşen ve çeşitli pratiklerle şekillenen bir inşadır. Bu anlamda Paris ekolü, Kopenhag ekolünden farklı olarak, güvenliğin ve güvenlikleştirmenin söylemsel inşasından daha ziyade bürokratik ve teknolojik pratikleri ile ilgilenir. ${ }^{52}$

Buna göre, Paris ekolü "Tehlikeli bir toplum yaratma sürecinde farklı aktörlerin birbirleriyle korku ve inançlarını paylaştı̆̆’”, "tedirginlik politikası” ile ilgilenmektedir. ${ }^{53}$ Burada bahsi geçen aktörler, ekol tarafından "güvenlik profesyonelleri" şeklinde isimlendirilmiş olup; askeri personel, istihbarat teşkilatları, polis kuvvetleri, özel güvenlik şirketleri, gazeteciler, ekonomistler, sağlık uzmanları ve akademisyenler gibi aktörleri kapsamaktadır. ${ }^{54}$ Bigo bu profesyonelleri “yönetişim tekniklerini” ve teknolojiyi kullanabilen "tedirginliğin yöneticileri” olarak tanımlar. ${ }^{55}$ CCTV kameralar, veri tabanları

48 Julie Wolfram Cox ve Stella Minahan, "Unravelling Woomera: Lip Sewing, Morphology and Dystopia”, Journal of Organizational Change Management, Cilt 17, No 3, 2004, s. 292-301.

49 Didier Bigo, "The Emergence of Consensus: Global Terrorism, Global Insecurity, and Global Security”, Ariane Chebel D’Appollonia ve Simon Riech (der.), Immigration, Integration, and Security: America and Europe in Comparative Perspective, Pittsburgh, University of Pittsburgh Press, 2008. s. 67-94.

50 Didier Bigo, "Security and Immigration: Toward a Critique of the Governmentality of Unease", Alternatives, Cilt 27, No 1, 2002, s. 63-92; Didier Bigo "Internal and External Aspects of Security”, European Security, Cilt 15, No 4, 2006, s. 385404; Bigo, "The Emergence of Consensus".

51 Jef Huysmans, The Politics of Insecurity: Fear, Migration and Asylum in the EU, Londra, Routledge, 2006, s. 153.

52 Diez ve Huysmans, "The Socio-Political Effects".

53 Bigo, "Security and Immigration", s. 63.

54 Ibid., s. 78; Didier Bigo, "International Political Sociology”, Paul D. Williams (der.), Security Studies: An Introduction, Londra, Routledge, 2008, s. 116-129.

55 Bigo, "Security and Immigration". 
oluşturma, profilleme ve yüz tanıma sistemleri geliştirme bu profesyoneller tarafından kullanılan teknik ve teknolojilere örnek olarak gösterilebilir. ${ }^{56}$ Paris ekolüne göre bu teknolojiler sayesinde güvenlik profesyonelleri güvensizlikleri belirli biçimlerde çerçevelendirebilir, dolayısıyla da bu güvensizliklere karşı ne gibi önlemlerin alınması gerektiğini belirleyebilir. ${ }^{57}$ Paris ekolüne göre bu teknolojilerin kullanımı aslen toplumsal olarak inşa edilerek güvenlikleştirilmiş bir konunun, siyasal olmaktan ziyade “teknik" bir mevzu olduğunu iddia etmeye olanak sağlar ve dolayısıyla bu konuların siyaset alanının dışına çıkarılması işlevi görür. Buna göre hem güvenlik hem de güvensizlik gündelik pratiklere işlemiş belirli bir "güvenliksizleştirme süreci" (insecuritization process) içerisinde ortaya çıkar. ${ }^{58}$ Paris ekolünün analizlerinde güvenliksizleştirme kavramına yapılan bu vurgu önemlidir çünkü ekol bu terim aracılı̆̆ıyla "ben ve öteki” ilişkilerine ya da birini güvenli kılmanın nasıl diğerlerinin güvensizliğine yol açtığına odaklanır. ${ }^{59}$

Göçün bir güvenlik konusu haline getirilmesi Paris ekolünün üzerine eğildiği en önemli alanlardan birini oluşturur. Bigo’ya göre göçün güvenlikleştirilmesi "siyasal bir teknolojidir" ve bu teknoloji "farklı kurumların tedirginlikle oynaması ya da henüz bu tedirginlik mevcut değilse ortaya çıkmasını teşvik etmesi, böylelikle kendilerinin koruma ve güvenlik sağlayıcıları rollerinin teyit edilmesi ve başarısızlıklarının gizlenmesi için bir yönetimsellik biçimi olarak kullanılır”. ${ }^{60}$ Yine Bigo'ya göre göç ve güvenlik arasındaki ilişki 1970’lerin ortasında kurulmaya başlasa da bu ilişki temelde Soğuk Savaş'ın sona ermesiyle ortadan kaybolan "mekansallaşmış düşmanın” yerine güvenlik profesyonellerinin yeni kaygılarına cevap vermek amacıyla "yeni potansiyel düşman” bulma arzusu neticesinde gelişmiştir. ${ }^{61}$

Göç ve güvenlik arasındaki bağlantıyı çalışırken Paris ekolü araştırmacıları çoğunlukla pratiklere odaklanırlar. Bunun nedeni "doğrudan bir tehdit olarak dile getirilmediğinde bile ilticanın, kurumsal ya da söylemsel olarak, kolluk faaliyetleri ya da savunmayı vurgulayan siyasal çerçevelere entegre edilerek, bir güvenlik konusu haline getirilebilecek" olmasıdır. ${ }^{62}$ Örneğin 2004 yılında Avrupa Birliği üyelerinin sınır ve sahil güvenliğini korumalarında gerekli koordinasyonun sağlanması amacıyla kurduğu "Avrupa Sınır ve Sahil Güvenlik Ajansı" (FRONTEX) üzerine yaptığı bir çalışmada Leonard, bu ajansın pratiklerinin göçün ve ilticanın güvenlikleştirilmesine nasıl katkıda bulunduğunu irdeler. ${ }^{63}$ Yazara göre "Ulusal sınır muhafızlarının eğitimi, risk analizlerinin yapılması ve sınır güvenliği ile ilgili araştırmaların takibi” ve "dış sınırlardaki ortak gözetim ve ortak iade operasyonlarının koordinasyonu” gibi pratikler, Avrupa’da göçün güvenlikleştirilmesi sürecini önemli ölçüde şekillendirmektedir. ${ }^{64}$

Güvenlik ve göç bağlantısını salt toplumsal güvenlik bağlamında ele alan Kopenhag ekolünün aksine, Paris ekolü bu bağlantıyı çalışırken iç güvenlik, toplumsal güvenlik, ekonomik güvenlik

56 Bigo, "International Political Sociology", s. 81.

57 Diez ve Huysmans, "The Socio-Political Effects".

58 Bigo, "The Emergence of Consensus", s. 116.

59 C.A.S.E. Collective, “Critical Approaches”, s. 461.

60 Bigo, "Security and Immigration”, s. 65.

61 Didier Bigo, "From Foreigners to Abnormal Aliens”, Elspeth Guild ve Joanne van Selm (der.), International Migration and Security: Opportunities and Challenges, Oxon, Routledge, 2005, s. 64-65.

62 Huysmans, The Politics of Insecurity, s. 4.

63 Sarah Leonard, "EU Border Security and Migration into the European Union: FRONTEX and Securitisation Through Practices”, European Security, Cilt 19, No 2, 2010, s. 231-254.

64 Ibid., s. 247. 
gibi farklı güvenlik sektörlerine odaklanır. ${ }^{65} \mathrm{Bu}$ kapsamlı bakış açısı ekolün "meşru üyelik kriterlerinin tartışılıp karara bağlandığı, polis ve gümrük gibi profesyonel birimler ile toplumsal hareketler ve siyasi partiler gibi siyasi kurumların dahil olduğu daha geniş teknolojik ve politik süreçlere" ${ }^{66}$ odaklanmasına yol açmaktadır.

Bigo'nun 11 Eylül saldırılarını takiben ortaya çıkan “Teröre Karşı Savaş” çerçevesini analiz ettiği çalışması bu noktaya örnek olarak verilebilir. ${ }^{67}$ Yazara göre bu çerçeve Avrupa Birliği ve Amerika Birleşik Devletleri’nde "Uzak veritabanları aracılığıyla bilgi paylaşımı, prosedürlerin standardizasyonu, yüksek hızlı ve güvenilir bilgi devreleri ve veri tabanındaki bilgilerin doğruluğunu belirlemek için daha iyi bir teknolojide ısrar eden" belirli güvenlik profesyonellerinin çıkarına hizmet etmektedir. ${ }^{68} \mathrm{Bu}$ güvenlik profesyonelleri kendi ülkelerindeki "ulusal güvenliği” koruma adı altında bazı havaalanlarında vücut ısısı ölçme veya yüz tanımayı mümkün kılan "kitlesel gözetim teknolojilerini” kullanmaktadırlar. ${ }^{69}$ Tüm bu pratikler "düşman imgesinin genişlemesiyle" sonuçlanmakta ve bu durum da en çok göçmen ve ilticacıları etkilemektedir. Dolayısıyla güvenlik profesyonellerinin göçmenleri "teröristlerle" ilişkilendirdiği, göçmenlerin varlığının dahi bu teknolojilerin kullanılmasını meşrulaştırmak için kullanıldığı bu tip durumlarda göç ve güvenlik arasındaki bağlantının güçlendiğini söylemek mümkündür.

Tüm bu bilgiler ışığında Paris ekolünün hem güvenlik kavramına hem de göç-güvenlik bağlantısına karşı olumsuz bir anlayışı olduğu söylenebilir. Roe'ya göre bu durum ekolün güvenliği "kazanan ve kaybedenlerin" olduğu "Schmitt'çi bir siyaset konsepti” ile özdeşleştirmesi ile ilgilidir. ${ }^{70} \mathrm{Bu}$ anlayış, göç-güvenlik ilişkisi bağlamında, ekolün güvenliği bireysel özgürlükleri kısıtlayan, "hareketlilik ve siyaset arasındaki ilişkide problemli bir aracı"11 olarak görmesine yol açmaktadır. Ekole göre güvenlik pratiklerinin göçmenler açısından yarattığı ayrımcı ve dışlayıcı politikalar buna bir örnektir. ${ }^{72}$ Bu nedenle Paris ekolü "Özgürlüğü daha az dışlayıcı ve daha az şiddetli bir şekilde yöneten ve şekillendiren alternatif siyasi düzen biçimlerini” "73 ortaya çıkaracak biçimde "güvenliği parçalamayı" (unmaking security) ${ }^{74}$ önerir. Fakat güvenliksizleştirme pratiklerine dair analizler ile karşılaştırıldığında, güvenliğin nasıl parçalanacağı sorusu görece olarak bu ekol tarafından yanıtsız bırakılmıştır. ${ }^{75}$

Paris ekolünün önerdiği bu çerçeve de literatürde eleştiri konusu olmuştur. Bu makalenin sorunsalı göz önünde bulundurularak bu bölümde iki ana eleştirinin altı çizilecektir. Öncelikle Paris ekolü güvenlik alanında birçok farklı kurum ve kuruluşa odaklanan "aktör bazlı bir yaklaşım" ${ }^{\text {”6 }}$ olmakla

65 Jef Huysmans, “The European Union and the Securitisation of Migration”, Journal of Common Market Studies, Cilt 38, No 5, 2000, s. 758.

66 Ibid., s. 751-752.

67 Bigo, "International Political Sociology".

68 Ibid., s. 79.

69 Ibid., s. 81.

70 Paul Roe, "Is Securitization a 'Negative' Concept? Revisiting the Normative Debate Over Normal versus Extraordinary Politics", Security Dialogue, Cilt 43, No 3, 2012, s. 258.

71 Huysmans ve Squire, "Migration and Security", s. 176.

72 Vicki Squire, The Exclusionary Politics of Asylum, Hampshire, Palgrave Macmillan, 2009.

73 Rens Van Munster, "Security on a Shoestring: A Hitchhiker's Guide to Critical Schools of Security in Europe", Cooperation and Conflict, Cilt 42, No 2, 2007, s. 239.

74 Huysmans, The Politics of Insecurity.

75 Bir istisna için bkz. Aradau, "Security and the Democratic Scene".

76 Waever, "Aberystwyth, Paris, Copenhagen: New Schools", s. 10. 
birlikte, ekolün yoğunlaştığı bu aktörler genellikle teknolojik ya da bürokratik güce erişimi olan kişilerdir. ${ }^{77}$ Diğer bir deyişle, ekol, Foucault'dan etkilenmesiyle de doğru orantılı olarak, "gücün nasıllığına" bakmakta ve "gücün mikro fiziği" ile ilgilenmektedir. ${ }^{78}$ Bunu yaparken farklı imkanlar, süreçler ya da yerleşik güç ilişkilerine direnen aktörler ekol tarafından yeterince dikkate alınmamaktadır. Örneğin göç alanında, göçmenlerin kendileri ya da göçmen hakları için mücadele eden STK'lar gibi farklı aktörler ekol tarafından yeterince analiz edilmemiştir. ${ }^{79}$ Booth'un deyişiyle ekol "şu anda açlık çeken, ezilen veya vurulan" "hiçbir şeyin profesyonelleri” (bu durumda göçmenler) olan aktörleri göz ardı etmiştir. ${ }^{80}$ Her ne kadar Paris ekolü bu tip bazı aktörlerin göçün güvenlikleştirilmesinden kaynaklanan olumsuz dinamiklere meydan okuduklarını kabul etse de, ekol bu aktörlerin polis ya da asker gibi "güvenlik profesyonellerine" klyasla etkilerinden şüphe etmektedir. ${ }^{81}$ Fakat Paris ekolü çerçevesi ile çalışan bazı akademisyenler bu kısıdın ötesine geçebilmişlerdir. Örneğin Huysmans güvenlik profesyonelleri dışındaki aktörlerin güvenlik alanındaki taktik ve pozisyonlarını analiz ederek bu kişilerin aktörlüklerinin altını çizmiştir. ${ }^{82}$ Benzer bir şekilde Nyers ampirik olarak bu aktörlüğü Kanada'daki Cezayirli mültecilerin iltica taleplerinin meşruluğunu ortaya koymadaki mücadeleleri üzerinden göstermektedir. ${ }^{83}$

Paris ekolüne getirilen ikinci bir eleştiri ise ampirik olarak ekolün çalıştığı vakaların genellikle Avrupa ve Kuzey Amerika'dan olmasıdır. Teorik olarak ise ekol "gelişmiş liberal toplumlardaki güç ilişkilerini kavramaya yönelik olarak geliştirilen bir metot" ${ }^{\text {" }}$ olan postyapısalcı yönetimsellik çerçevesini kullanmaktadır. Bu nedenle bu ekolün önerdiği çerçeve her ne kadar bazı merkez dışı bağlamlardaki göçün güç sahipleri tarafından güvenlikleştirilmesi vakalarını analiz etmek için kullanılsa da, ${ }^{85}$ bu ekolün merkez dışındaki yerlerdeki güvensizlikleri anlamada ve bunlara çözüm önermede sınırlı kaldığı söylenebilir.

Sonuç olarak, Paris ekolü göç-güvenlik bağlantısını anlamak için literatüre çok boyutlu bir çerçeve önermektedir. Bu çerçeve göçün sadece söylemsel olarak bir güvenlik konusu haline getirilmediğini, bu süreçteki pratiklerin de önemli olduğunu vurgular. Aynı zamanda göçün güvenlikleştirilmesini salt toplumsal güvenlik bağlamında değil, aynı zamanda ekonomik güvenlik, iç güvenlik gibi farklı sektörlerde de inceler. Fakat kimi yazarlara göre ekolün bu konuyu anlamada çeşitli kısıtları vardır. İlk olarak ekol toplumda gücü elinde bulunduran aktörlere odaklanarak, diğer aktörleri büyük ölçüde göz ardı etmiştir. İkinci olarak ekol hem kuramsal hem de ampirik anlamda merkez ülkelere odaklanmış, bunun neticesinde de merkez dışındaki güvensizlikleri anlayıp, bunların ötesine geçmede kısıtlı kalmıştır.

77 Peter Nyers, “Taking Rights, Mediating Wrongs: Disagreement over the Political Agency of Non-State Refugees”, Jef Huysmans, Andrew Dobson ve Raia Prokhovnik (der.), The Politics of Protection: Sites of Insecurity and Political Agency, Oxon, Routledge, 2006, s. 49.

78 Jan Selby, “Engaging Foucault: Discourse, Liberal Governance and Limits of Foucauldian IR”, International Relations, Cilt 21, No 3, 2007, s. 324-345.

79 Bilgiç, Rethinking Security, 6-7.

80 Aktaran, C.A.S.E Collective, “Critical Approaches”, s. 459.

81 Nyers, “Taking Rights”, s. 54.

82 Huysmans, "Agency and the Politics", s. 9.

83 Nyers, "Taking Rights".

84 Nicholas J Kiersey ve Jason R. Weidner, “Editorial Introduction”, Global Society, Cilt 23, No 4, 2009, s. 358.

85 Buna bir örnek için bkz. Burcu Toğral Koca, "Syrian Refugees in Turkey: from “Guests” to “Enemies?”, New Perspectives on Turkey, Cilt 54, No 1, 2016, s. 55-75. 


\section{Kısıtların Ötesine Geçmek: Aberystwyth Ekolü’nün Özgürleşme Yaklaşımı ${ }^{86}$}

Aberystwyth ekolünün temelleri Aberystwyth Üniversitesi'nde güvenlik alanında çalışan iki önemli akademisyen olan Ken Booth ve Richard Wyn Jones'un yazınlarıyla atılmıştır. Ekolün felsefi temelinde ise Frankfurt ekolü ve Gramscici eleştirel kuramı bulmak mümkündür. ${ }^{87} \mathrm{Bu}$ ekol güvenliği "türetilmiş bir kavram” (derivative concept) olarak görür. Bunun anlamı şudur: Bir kişinin siyasal ve felsefi duruşu onun güvenlik konusundaki fikirlerini şekillendirir. ${ }^{88}$ Kopenhag ve Paris ekollerinin aksine bu ekolün belirli bir güvenlik tanımı vardır ve ekol güvenliğe pozitif bir anlam yükler. Booth’a göre şayet güvenliğe sahip olmak istiyorsak öncelikle onu tanımlamamız gerekir. ${ }^{89}$ Kendisi bu kavramı şöyle tanımlar:

“'Güvenlik' tehdidin yokluğu anlamına gelir. Özgürleşme, insanların (bireyler ve gruplar olarak) serbestçe seçecekleri şeyleri yapmalarını engelleyen fiziksel ve insani kısıtlamalardan kurtulmalarıdır. Savaş ve savaş tehdidi; yoksulluk, kötü eğitim, politik baskı vb. ile birlikte bu kısıtlamalardan biridir. Güvenlik ve özgürleşme aynı madalyonun iki yüzüdür. Gerçek güvenliği güç veya düzen değil özgürleşme sağlar. Özgürlüşme, kuramsal olarak, güvenliktir." ${ }^{\circ 0}$

"Özgürleşme" (emancipation) bu ekol tarafından eleştirel güvenlik çalışmalarının amacı olarak kabul edilir. ${ }^{91} \mathrm{Bu}$ kavram aracılığıyla Aberystwyth ekolü geleneksel güvenlik anlayışlarını yapı söküme uğrattıktan sonra "yeniden inşa etme" (reconstruction) sürecine girer. Booth’a göre özgürleşme insanların normalde yapmayı tercih edecekleri şeyleri yapmalarına engel teşkil eden baskılara karşı insanları güvenceye almak ve bunu yaparken de başkalarının özgürlüklerini kısıtlamamak demektir. ${ }^{92}$

Ekole göre güvenlik "insan hakları ihlalleri, azınlıklara uygulanan baskılar, fakirlerin güçsüzlüğ̈̈, kadına karşı şiddet” gibi durumları gün ışığına çıkartmak suretiyle özgürleşmeye yol açabilir. ${ }^{93} \mathrm{Bu}$ noktada altı özellikle çizilmesi gereken nokta ekolün özgürleşme kavramının "şeyleştirilmesinin" ( $r e-$ ification) önüne geçmek için bu kavramı bir son nokta, varış yeri olarak değil, aksine bir süreç ve yön olarak kavramsallaştırmasıdır. ${ }^{44}$ Bunun yanı sıra özgürleşme bu ekolün önerdiği çerçeve içinde soyut bir yere sahip olmaktan ziyade fiili bir değere sahiptir. Bunun nedeni özgürleşmenin anlamını ekolün gerçek kurum ve ilişkilere bakarak tanımlamasıdır. ${ }^{95} \mathrm{Bu}$ anlamda özgürleşme "gerçekleştirilebilir değişimlerin imkanlarının ana hatlarını belirlemede" kullanılan bir kavramdır. ${ }^{96}$

Aberystwyth ekolüne göre ontolojik olarak güvenliğin referans nesnesi bireylerdir, yani "kimin güvenliği?” sorusuna bu ekol "bireyler” cevabını vermektedir. Booth’a göre güvenlik çalışmalarında

86 Bu ekol literatürde "Welsh/Galler ekolü”, “özgürleştirici realizm”, “özgürleşme olarak güvenlik” ya da “Eleştirel Güvenlik Çalışmaları” (ilk harfleri büyük yazılmaktadır) olarak da bilinmektedir.

87 Pınar Bilgin, “Critical Theory”, Paul D. Williams (der.), Security Studies: An Introduction, Londra: Routledge, 2008, s. 89-102.

88 Ibid., s. 90.

89 Ken Booth, "Security and Emancipation", Review of International Studies, Cilt 17, No 4, 1991, s. 317.

90 Ibid., s. 319.

91 Wyn Jones, Security, Strategy, s. 5.

92 Booth, Theory of World Security, s. 112.

93 C.A.S.E. Collective, “Critical Approaches”, s. 456.

94 Wyn Jones, Security, Strategy, s. 77-78

95 Ibid., s. 76.

96 Matt McDonald, Security, the Environment and Emancipation: Contestation over Environmental Change, Oxon, Routledge, 2012 , s. 45 
devletlerin merkezi bir referans nesnesi olarak alınması problemlidir ve bu sorun, araçların amaçlarla karıştırılmasına neden olmaktadır. ${ }^{97} \mathrm{Bu}$ anlamda güvenliği devletler, STK'lar, bireyler gibi farklı aktörler sağlayabilirken, korunması gereken asıl aktörler bireylerdir. ${ }^{98}$

Wyn Jones’a göre bireyleri ana referans nesnesi kabul eden bu anlayış, Frankfurt ekolünün önemli temsilcilerinden biri olan Horkheimer'dan gelmektedir:

\begin{abstract}
"Horkheimer, eleştirel teorinin insanın fiziksel, maddi varlığı ve deneyimleriyle ilgilenmesi gerektiğine inanıyordu. Bunu savunurken sınıfın, devletin veya diğer kolektivitelerin önemini ise reddetmiyordu. Gerçekten de Horkheimer'ın bireysel insanların varlığının ve deneyimlerinin bu tür bağlamların bir parçası olarak görülmeden anlaşlabileceğini düşünmediği açıktır. Aksine, onun sürekli vurguladığı şey, toplumlar ve kurumların içindeki çeşitli dinamikleri analiz ederken teorisyenlerin bunların bireysel insanlar üzerindeki etki ve anlamları ile ilgili görüşlerini asla kaybetmemeleri gerektiğidir." ${ }^{\prime 9}$
\end{abstract}

Aberystwyth ekolü için bireyleri güvenliğin referans noktası olarak almak sadece normatif bir öneme sahip değildir, bunun aynı zamanda analitik bir önemi de vardır. Çünkü bu anlayış analistlere farklı bağlamlarda yaşayan farklı bireylerin güvensizliklerini anlamaya yönelik bir çerçeve sunarken, aynı zamanda bu bağlamların şeyleştirilmesinin de önüne geçmektedir. ${ }^{100}$

Kopenhag ve Paris ekollerinin aksine Aberystwyth ekolü güvenlik-dışılaştırma kavramına evrensel bir değer atfetmez ve güvenlik-dışılaştırmayı gerekli bir edim olarak görmez. Bu ekol için asıl yapılması gereken "güvenliğin siyasiliğini" ortaya koymaktır. ${ }^{101}$ Güvenliğin siyasiliğinin ortaya koyulmasındaki amaç "güvenlik pratiklerini özgürleştirici, yeniden yapılandırıcı bir maksatla yeniden düşünüp revize etmektir”. ${ }^{12}$ Güvenliğin siyasiliğinin ortaya koyulması üç ana argüman çevresinde şekillenir. ${ }^{103}$ Bunlardan ilki stratejiktir: Güvenlik kavramı, bireylerin güvenliği konusundaki yaklaşımları tartışmalı olabilen elitlerin tekelinden çıkarılmalıdır. İkincisi ise "etik-politiktir": "Güvenliğin geleneksel olarak devlet ve devletin kaygıları ile ilgili olmuş olduğu gerçeği, bu şekilde kalması gerektiği anlamına gelmez. Siyasi tercihler çerçevesinde güvenliğin insanların endişelerini içerecek şekilde genişlemesi mümkündür”. ${ }^{104}$ Üçüncü argüman ise analitiktir: Güvenliğin siyasiliğinin ortaya konması sorunlar hakkındaki farkındalığı arttırıp, bu sorunlara çözüm bulunmasına katkı sağlar.

Literatürde Aberystwyth ekolünün önerdiği çerçeveden hareketle göç-güvenlik ilişkisine bakan kısıtlı sayıda yayın vardır. ${ }^{105} \mathrm{Bu}$ makale, bu ekolün yaklaşımının göç-güvenlik alanında daha da geliştirilmesi gerektiğini vurgulamaktadır. Bunun nedeni Aberystwyth ekolünün ortaya koyduğu iki anlayış ile ilgilidir. Öncelikle ekol bireyleri güvenliğin referans nesnesi ve aktörü olarak tanımlaya-

97 Booth, "Security and Emancipation", s. 319.

98 McDonald, Security, the Environment, s. 43.

99 Wyn Jones, Security, Strategy, s. 115.

100 Ibid., s. 78.

101 Pınar Bilgin, “Güvenlik Çalışmalarında Yeni Açılımlar: Yeni Güvenlik Çalışmaları”, Stratejik Araştırmalar, Cilt 8, No 14, 2010, s. 84.

102 Booth, Theory of World Security, s. 172.

103 Bilgin, "Güvenlik Çalışmalarında", s. 84.

104 Ibid., s. 85.

105 Bu duruma bir istisna 2013 yılında Ali Bilgiç tarafından yazılmış olan Rethinking Security in the Age of Migration: Trust and Emancipation in Europe isimli kitaptır. Bu kitapta yazar mülteciler ya da sığınmacılar yerine "koruma arayan düzensiz göçmenler” kategorisini önermekte ve analizini bu gruba referansla tartışmaktadır. Yazar aynı zamanda vaka olarak Sahra Altı Afrika'dan Avrupa Birliği ülkelerine giden göçmenlere odaklanmaktadır. 
rak ve güvenlik-dışılaştırma yerine güvenliğin siyasiliğinin ortaya koyulması gerektiğinin altını çizerek, göç alanında deneyimlenen çeşitli güvensizliklerin ötesine nasıl geçebileceğimizi düşünmek için alan açmaktadır. İkinci olarak günümüzde Güney-Güney göçünün yaygınlığı göz önüne alındığında Aberystwyth ekolünün önerdiği çerçevenin özellikle merkez dışı bağlamları anlamada önemli olmasıdır. Aşağıda bu iki nokta sırasıyla detaylı bir biçimde ele alınacaktır.

Aberystwyth ekolüne göre uluslararası ilişkiler dünyadaki farklı eşitsizlik ve baskı ilişkileri çerçevesinde şekillenir. Bu eşitsizlikler ya da ilişkiler kapitalizm, ataerkillik, rrkçılık, milliyetçilik gibi farklı nedenlerden kaynaklanır. ${ }^{106}$ Günümüz uluslararası ilişkilerinde temel konular arasında kabul edilen göç konusu da mevcut küresel düzenden ve onun meydana getirdiği, üretimin küreselleşmesinin sebep olduğu ekonomik eşitsizlikler, savaşlar ya da ekolojik problemlerden azade bir biçimde anlaşılamaz. $\mathrm{O}$ halde, göçün sebepleri küresel dinamiklere işaret ederken, göç kaynaklı güvensizlik yaşayan bireylerin sorunlarının çözümü de tüm insanların, bilhassa da kaynaklara erişimi olan kimselerin, sorumluluğundadır. ${ }^{107}$

Öyleyse Aberystwyth ekolüne göre dünya politikasındaki dinamiklerden dolayı zor duruma düşmüş bu kimselerin “özgürleşmesi” gerekmektedir. Bunu elde edebilmek için ise bu bireyleri güvenliğin temel referans nesnesi olarak kabul etmek ve hem onları hem de onlarla dayanışma içerisine girecek diğer kişi/kurumları güvenliğin aktörleri olarak düşünmek önemlidir; yani göç-güvenlik bağlantısını ontolojik olarak farklı bir biçimde anlamamız elzemdir. Çünkü bu bağlantı kurulurken "tehdit" olarak gösterilen bireylerdir. Bu temsilin göçmen ve mültecilere karşı birçok dışlayıcı ve ayrımcı söylem ve pratik doğurduğu ise yadsınamaz bir gerçektir. Bunun bir örneği ailesiyle Suriye’deki savaştan kaçarak Avrupa'ya varmaya çalışan 3 yaşındaki Alan Kurdi'nin Bodrum'da bir deniz kıyısında boğulmuş bir şekilde bulunmasıdır. Browning'e göre Aylan'ın ölümünün sebeplerinden birisi "Avrupa devletlerinin göçmen ve mültecilerin akışını sınırlandırmak için daha katı sınır ve iltica rejimleri kullanma arzusudur”. ${ }^{108} 2018$ yılının Mayıs ayına kadarki süreçte Avrupa Birliğinin bu kısıtlayıcı göç politikaları neticesinde, 34.361 kişi hayatını kaybetmiştir. ${ }^{109}$

Aberystwyth ekolünde güvenliğin referans nesnesi olan bireyler yalnızca mülteciler ve göçmenler değil, aynı zamanda bu kişilerin gittiği ülkelerdeki vatandaşlardır. Örneğin 2013 yılında yayınlanan "Göç Çağında Güvenliği Yeniden Düşünmek: Avrupa'da Güven ve Özgürleşme” (Rethinking Security in the Age of Migration: Trust and Emancipation in Europe) isimli çalışmasında Ali Bilgiç, Aberystwyth ekolünün çerçevesini kullanarak bu noktanın öneminin altını çizmektedir. ${ }^{110}$ Yazar bu eserinde "baskın güvenlik ilişkilerinin özgürleştirici yapılarla değiştirilmesine katkıda bulunabilecek” ve hem koruma arayan düzensiz göçmenlerin hem de göç alan topluluklardaki kişilerin güvenlikten birlikte yararlanmalarını sağlayabilecek fikir ve uygulamaları incelemektedir. ${ }^{111}$ Bilgiç’e göre koruma arayan düzensiz göçmenler ve ev sahibi ülke vatandaşlarının arasında kurulacak, karşılıklı güvene dayalı bir "biz" hissiyatı insan hakları ve özgürlüklerin başat olduğu, özgürleştirici siyasal yapıları ortaya çıkarabilir. ${ }^{112}$

106 Booth, Theory of World Security, s. 21.

107 Marcos Farias Ferreira, "Critical Theory", Stephan McGlinchey, Rosie Walters ve Christian Scheinpflug (der.), International Relations Theory, Bristol, E-International Relations Publishing, 2017, s. 53-54.

108 Christopher S. Browning, "Security and Migration: A Conceptual Exploration”, Philippe Bourbeau (der.), Handbook on Migration and Security, Cheltentam, Edward Elgar, 2017, s. 40.

109 UNITED, "List of 34,361 documented deaths of refugees and migrants due to the restrictive policies of 'Fortress Europe”, 5 Mayıs 2018, https://uploads.guim.co.uk/2018/06/19/TheList.pdf (Erişim Tarihi 6 Şubat 2019).

110 Bilgiç, Rethinking Security.

111 Ibid., s. 2.

112 Ibid., s. 3. 
“Güvenliğin aktörleri kimdir?” sorusuna verdikleri cevap, Aberystwyth ekolünün göç-güvenlik ilişkisini düşünmede bize sunacağı katkılardan bir diğeridir. Yalnızca politikacılar, elitler, ya da güvenlik profesyonelleri ile ilgilenmeyen ekol, "insanların farklı ihtiyaçlarını karşılamaya çalışan"113 birçok farklı aktörün (STK’lar, toplumsal hareketler gibi) öneminin altını çizer. Göç ve iltica alanında koruma sağlamadan, yardım faaliyetlerine, politikaların, standartların, normların oluşturulmasından bunların uygulamalarının gözlemlenmesine kadar birçok farklı adımda STK'lar oldukça aktiftir. ${ }^{114} \mathrm{Bu}$ STK ya da diğer aktörler göçmen ve mültecilerle birebir çalışmakta, göç ve iltica konularında toplumda farkındalık oluşturmakta ve bazı durumlarda çeşitli değişimlerin öncülüğünü yapabilmektedirler.

Yukarıdaki bölümlerde de tartışıldığı üzere hem Kopenhag hem de Paris ekolleri göçün güvenlikle özdeşleştirilmesinin olumsuz sonuçlarını göz önünde bulundurarak, göç konusunun güvenliğin dışına taşınması gerektiğini savunmaktadırlar. Fakat bu, yine yukarıda belirtildiği üzere, bu ekollerin göreli olarak üzerine daha az eğildiği bir konudur. Buradan hareketle şu söylenebilir: Bu ekoller güvenlikleştirmenin süreci ile daha çok ilgilenmiş, fakat bu sürecin yarattığı olumsuz sonuçların nassıl aşılabileceği konusunda görece daha az tartışma üretmişlerdir. Floyd'un da belirttiği gibi güvenlikleştirme yaklaşımı, güvenlik analistinin ne zaman bir güvenlikleştirme/güvenlik-dışılaştırma olduğunu, bunun nasıl gerçekleştiğini ve bu sürece hangi aktörlerin dâhil olduğunun belirlenmesini sağlayan bir süreç takibi aracıdır; fakat analistin asıl amacı bireyler ve grupların deneyimlediği güvensizliklerin altını çizmek olmalıdır. ${ }^{115}$

Bu noktada bireylerin yaşadığı güvensizliklerin altının nasıl çizebileceği sorusu öne çıkmaktadır. Burada güvenliği olumsuz bir kavram olarak kabul eden ve göçün güvenlik konusu dışına çıkarılmasını öneren Kopenhag ve Paris ekollerinden farklı olarak güvenliğin olumlu bir şekilde yeniden tanımlanması önerilebilir. ${ }^{116}$ Çünkü, Bilgin’in de altını çizdiği gibi güvenlik kavramı etrafında yürütülen bir tartışma "ilerici bir değişim aracı olabilir”."17 Örneğin Elbe, HIV/AIDS'in güvenlikleştirilmesinin bu hastalık hakkında bilincin artması ve bu hastalıkla savaşta gerekli kaynakların mobilize edilmesi açısından faydalı olabileceğinin altını çizmektedir. ${ }^{118}$ Benzer bir şekilde, Floyd çevresel güvenliğin insan güvenliği olarak ele alınmasının, "çevresel değişimin temel nedenlerini, hepimiz için sağlıklı ve işleyen bir çevre oluşturmak amacıyla (küresel) işbirliği tedbirlerinin ele alınmasını” mümkün kıldığı için istenilen bir gelişme olduğunu vurgulamaktadır. ${ }^{19}$ Göç alanında ise güvenliğin özgürleşmeye ${ }^{120}$ referansla tekrar ele alınması ve bireylerin deneyimlediği güvensizliklerin, onların aktörlüklerinin analiz edilmesi hem göçmenler/mülteciler hem de göç alan ülke vatandaşları için olumlu sonuçlar doğurabilir. ${ }^{121}$ Bunun nedeni güvenliği siyasallaştırmanın bireylerin yaşadığı sorunlar ve bu sorunların olası çözümlerini açıkça tartışmak için uygun platformlar yaratılmasını sağlayabilecek olmasıdır.

113 Pınar Bilgin, "Individual and Societal Dimensions of Security", International Studies Review, Cilt 5, No 2, 2003, s. $216-217$.

114 Eve Lester, "A Place at the Table: The Role of NGOs in Refugee Protection: International Advocacy and Policy Making”, Refugee Survey Quarterly, Cilt 24, No 2, 2005, s. 125.

115 Rita Floyd, "Human Security and the Copenhagen School's Securitization Approach: Conceptualizing Human Security as a Securitizing Move”, Human Security Journal, Cilt 5, No 4, 2007, s. 39-42.

116 Joao Nunes, "Reclaiming the Political: Emancipation and Critique in Security Studies", Security Dialogue, Cilt 43, No 4, 2012, s. 348.

117 Bilgin, “Making Turkey's Transformation”, s. 560.

118 Stefan Elbe, "Should HIV/AIDS Be Securitized? The Ethical Dilemmas of Linking HIV/ AIDS and Security", International Studies Quarterly, Cilt 50, No 1, 2006, s. 119-44.

119 Rita Floyd, Security and the Environment: Securitisation Theory and US Environmental Security Policy, Cambridge, Cambridge University Press, 2010, s. 184.

120 Özgürleşme terimine dair alternatif bir kavramsallaştırma için bkz. Aradau, "Security and the Democratic Scene".

121 Bilgiç, Rethinking Security. 
Göç-güvenlik ilişkisini düşünürken, Aberystwyth ekolü tarafından önerilen çerçeveye dayanan çalışmaların zenginleştirilmesi ihtiyacının diğer bir nedeni olarak bu makale merkez dışı bağlamlarda yaşanan güvensizliklerin bu ekol tarafından daha iyi analiz edilebilecek olmasını göstermektedir. Literatürde bazı akademisyenler bu ekolün de merkez dışı bağlamları anlamada kısıtları olduğunu dile getirmiş ve örneğin özgürleşme kavramının liberal değerlere dayanan "Batılı" bir kavram olduğunu belirtmişlerdir. ${ }^{122} \mathrm{Bu}$ eleştirilere cevap olarak Nunes ve Basu özgürleşme kavramının Aberystwyth ekolü tarafından evrensel olarak ele alınmadığını, aksine bu kavramın "somut durumlarda sadece yerel paydaşlar tarafından belirlenebilen” yerelleştirilmiş bir sürece işaret ettiğinin altını çizmektedirler. ${ }^{123}$ Yine Nunes ekolün güvenliğin anlamını önceden belirlenmiş evrensel bir anlayışa dayanmadığını, bu anlamın belirli bağlamlardaki kişilerin deneyimlediği güvensizlikler ile belirlendiğini dile getirmektedir. ${ }^{124}$ Booth da özgürleşmeyi “Batı” nın ya da başka aktörlerin gücünü örten, onları "bilgeliğin tekeline sahip olma” iddiasını meşrulaştıran bir araç olarak tanımlamanın "yanlış bir özgürleşme” anlayışı olduğunu vurgulamaktadır. ${ }^{125}$

$\mathrm{Bu}$ eleştirilere gelen bir diğer cevap da bu ekolün kendi sınırlarının üzerine düşünme potansiyelinin altını çizen çalışmalardır. ${ }^{126}$ Örneğin Alker, Aberystwyth ekolünün ayırt edici niteliklerinden olan özgürlük ve özgürleşme gibi kavramlardan vazgeçmeden, bunların anlamını birçok farklı "Batı" ve "Batı dış”" perspektifi kapsayacak şekilde tekrar düşünmeyi önerir. ${ }^{127} \mathrm{Bu}$ anlamda, örneğin, Lee-Koo özgürleşme kavramını "Batı dışı ve postkolonyal eleştirel feministlerin” anlayışlarını kapsayacak bir biçimde tekrar düşünmek gerektiğini belirtir. ${ }^{128}$

Bu noktayla ilişkili olarak Waever Aberystwyth ekolünün "Batı dışı bağlamlarda belki de en kolay mobilize edilebilecek ekol” olduğunu vurgulamaktadır. ${ }^{129}$ Bilgin ise ekolün Küresel Güney’de karşılaşılan güvensizlikleri açıllamada ve bu güvensizliklerden kurtulma yolunda önemli katkılar yaptığını dile getirmektedir. ${ }^{130} \mathrm{Bu}$ argümanlarla doğru orantılı olarak literatürde Aberystwyth ekolünün farklı merkez dışı bağlamlardaki, örneğin Orta Doğu'daki, Asya-Pasifik'teki ya da Afrika'daki güvensizliklerin çalışılmasında kullanıldığını görmekteyiz. ${ }^{131}$ Fakat yine de göç-güvenlik bağlantısı özelinde bu ekolün çerçevesi kullanılarak merkez dışı bağlamları anlamaya yönelik yapılan çalışmalar şu ana kadar yeterince gelişmemiştir. Aşağıdaki bölümde bu eksiğin ötesine geçebilmek adına Aberystwyth ekolünün önerdiği çerçeve ile Türkiye'deki Suriyeli mülteciler örneği ele alınacaktır.

122 Örneğin, bkz. Tarak Barkawi ve Mark Laffey, “The Postcolonial Moment in Security Studies”, Review of International Studies, Cilt 32, 2006, s. 329-352; Karin M. Fierke, Critical Approaches to International Security, Cambridge, Polity, 2015.

123 Soumita Basu ve Joao Nunes, “Security as Emancipation”, Laura J. Shepherd (der.), Critical Approaches to Security: An Introduction to Theories and Methods, Oxon, Routledge, 2013, s. 68.

124 Nunes, "Reclaiming the Political”, 351.

125 Booth, Theory of World Security, 113.

126 Pınar Bilgin, The International in Security, Security in the International, Oxon, Routledge, 2017, s. 53.

127 Hayward Alker, "Emancipation in the Critical Security Studies Project”, Ken Booth (der.), Critical Security Studies and World Politics, Boulder, Lynne Rienner, 2005, s. 200.

128 Katrina Lee-Koo, "Security as Enslavement, Security as Emancipation: Gendered Legacies and Feminist Futures in the Asia-Pacific”, Anthony Burke ve Matt McDonald (der.), Critical Security in the Asia-Pacific, Manchester, Manchester University Press, 2007, s. 243.

129 Waever, "Aberystwyth, Paris, Copenhagen: the Europeanness", s. 52.

130 Pinar Bilgin, “The Continuing Appeal of Critical Security Studies”, Shannon Brincat, Laura Lima ve Joao Nunes (der.), Critical Theory in International Relations and Security Studies: Interviews and Reflections, Oxon, Routledge, 2012, s. 160-166.

131 Sirasıyla, bkz. Pınar Bilgin, Regional Security in the Middle East: A Critical Perspective, Londra, Routledge Curzon, 2005; Anthony D. Burke ve Matt McDonald (der.), Critical Security in the Asia-Pacific, Manchester, Manchester University Press, 2007; Paul D. Williams, “Thinking about Security in Africa”, International Affairs, Cilt 83, No 6, 2007, s. 1021-1038. 


\section{Türkiye'deki Suriyeli Mülteciler Örneği ve Aberystwyth Ekolü}

Türkiye, 2011 yılında başlayan ve ilerleyen yıllarda şiddetlenerek devam eden Suriye İç Savaşından kaçan Suriyelilerin en yoğunluklu olarak bulundukları ülkedir. Göç İdaresi Genel Müdürlügü’nün Şubat 2020 verilerine göre Türkiye'de geçici koruma altında 3 milyon 587 bin 266 Suriyeli mülteci vardır. ${ }^{132}$ Türkiye'deki Suriyeli mültecilerin 64 bin 48'i geçici barınma merkezlerinde kalırken, diğer mülteciler bu merkezlerin dışında, farklı şehirlerde ikamet etmektedirler. Hem Suriyeli mülteciler hem de İran, Irak, Afganistan gibi ülkelerden kaçan mültecilerin toplam sayısı göz önünde alındığında Türkiye dünyada en çok sayıda mülteciye sahip ülkedir. ${ }^{133}$

Suriyeli mültecilerin Türkiye'ye gelmeye başladıkları ilk yıllarda bu kişilerin ülkede kısa bir süre için kalacakları ve en yakın zamanda Suriye’ye geri dönecekleri düşünülmekteydi. ${ }^{134}$ Fakat aradan geçen zaman içerisinde bu algı yıkılmış, Suriyeli mültecilerin Türkiye'de uzun süre kalacakları ve geri dönüş seçeneğinin gerçekleştirilebilir bir seçenek olmaktan uzak olduğu ortaya çıkmıştır. ${ }^{135} \mathrm{Bu}$ nedenle "şu anda Türkiye'deki mültecilerle ilgilenmek, mülteci akınını durdurmayı veya mültecilerin hareketlerini tersine çevirmeyi değil, onlara daha iyi yerleşim ve entegrasyon firsatları sunmayı amaçlayan pratik tedbirler" almayı gerekli kılmıştır. ${ }^{136}$

İşte bu tedbirlerin belirlenmesinde ihtiyacımız olan noktalardan biri Türkiye'deki Suriyeli mülteciler olgusu etrafında ortaya çıkan çok çeşitli güvensizliklerin belirlenip tartışılmasıdır. Bu tartışmanın şekillenmesinde Aberystwyth ekolünün önerdiği çerçeve iki açıdan önem teşkil etmektedir. İlk olarak, Türkiye merkez dışı bir ülkedir ve dolayısıyla Güney-Güney göçündeki dinamiklerin anlaşılmasında önemli bir örnek oluşturmaktadır. Aşağıda daha detaylı inceleneceği üzere bu merkez dışı bağlam hem mültecilerin hem de Türkiye vatandaşlarının deneyimledikleri güvensizlikleri şekillendirmektedir. Aberystwyth ekolünün bu vakayı anlamada bize sunacağı ikinci katkı ise bireylerin güvenliğin referans nesnesi ve aktörü olarak kabul edilmesi ile ilişkilidir.

\section{Merkez Dışı Bağlamları Anlamak}

Göç çalışmaları alanındaki yazarlara göre Güney-Güney göçü çok uzun zamandır süregiden bir olgu olmasına rağmen, bu alana akademik ilgi görece yeni ortaya çıkmış, bu nedenle de bu alan yeteri kadar gelişmemiştir. ${ }^{137}$ Bunun nedeni göç olgusunun literatürde, eksik bir biçimde, bir Güney-Kuzey olgusu olarak ele alınması ve göç alanındaki analizlerin hatlarını, Kuzey ya da merkez aktörlerin deneyimlerinin belirlemesidir. Bu durum özellikle zorunlu göçteki küresel eğilimlere bakıldığında şaşırtıcıdır. Bank ve Fröhlich’in de belirttiği üzere zorunlu göç temel olarak Afrika, Asya, Latin Amerika ve Orta Doğu içerisinde veya arasında gerçekleşmektedir. ${ }^{138}$ Örneğin, 2018 yılı Birleşmiş Milletler Mülteciler

132 Göç İdaresi Genel Müdürlüğü, https://www.goc.gov.tr/gecici-koruma5638 (Erişim Tarihi 7 Mart 2020).

133 UNHCR, “Global Trends: Forced Displacement in 2018”, 2018, https://www.unhcr.org/globaltrends2018/ (Erişim tarihi 2 Temmuz 2019).

134 Ahmet İçduygu ve Doğuş Şimşek, “Syrian Refugees in Turkey: Towards Integration Policies”, Turkish Policy Quarterly, Cilt 15, Sayı 3, 2016, s. 60.

135 Ahmet İçduygu ve Enes Ayaşlı, “Geri Dönüş Siyaseti: Suriyeli Mültecilerin Dönüş Göçü İhtimali ve Gelecek Senaryoları”, MiReKoc Çalışma Notları, 2019, s. 1-17.

136 İçduygu ve Şimşek, “Syrian Refugees, s. 60.

137 Beatriz Campillo-Carrete, “South-South Migration: A Review of the Literature.” ISS Working Paper Series, 2013, s. 1-89; Jonathan Crush ve Abel Chikanda, "South-South Migration and Diaspora”, Elena Fiddian-Qasmiyeh ve Patricia Daley (der.), Routledge Handbook of South-South Relations, Oxon, Routledge, 2019, s. 380-396.

138 Andre Bank ve Christiane Fröhlich, "Forced Migration in the Global South: Reorienting the Debate”, GIGA Focus Global, 
Yüksek Komiserliği verilerine göre Türkiye dünyada en çok mülteci sayısına sahip ülke olurken (3.7 milyon), onu sırasıyla Pakistan (1.4 milyon), Uganda (1.2 milyon) ve Sudan (1.1. milyon) izlemektedir. ${ }^{139}$ Yazarlar bu nedenle zorunlu göç olgusuna bakılırken analizlerin odağının bu konunun merkezi ülkelere olan etkisinin olmaması gerektiğinin, Güney'de vuku bulan deneyimler ve bağlamsal faktörlere odaklanmanın gerektiğinin altını çizmektedirler.

İşte bu noktada Aberystwyth ekolünün "coğrafi ve tarihsel faktörlere"140 karşı olan hassasiyeti, "gerçek insanların gerçek yerlerde" ${ }^{41}$ deneyimlediği güvensizliklere dair dikkati ve "kültüre duyarlı ve pragmatik, fakat aynı zamanda evrensel” ${ }^{142}$ yaklaşımının önemi ortaya çıkmaktadır. Türkiye özelinde bu ekol bize hem ülkenin bağlamını anlayabilmek hem de Türkiye'deki göçün belirli bir güvenlik anlayışı ile ilişkilendirilmesinin olumsuz sonuçlarının ötesine geçme yolundaki çözümleri formüle etmek için önemli kavramsal anlayışlar sunmaktadır.

$\mathrm{Bu}$ anlamda, Aberystwyth ekolünün argümanlarının ışığında Türkiye örneğinde yapılması gereken göç ve iltica alanını güvenlik-dışılaştırmadan ziyade, bu alanda güvenliğin siyasiliğini ortaya koymaktır. Diğer bir deyişle, Türkiye'deki Suriyeli mülteciler vakasında yapılması gereken "güvenlik nedir?" sorusuna siyasi elitler ve karar alıcıların olası cevaplarının ötesinde, bireylerin deneyimledikleri güvensizliklerden yola çıkarak cevap vermek, yine sıradan insanların karşılaştıkları tehditlere dair farkındalığı arttırmak ve böylelikle bu güvensizliklerin giderilmesi için oluşturulacak politikaları şekillendirmektir. ${ }^{143}$ Çünkü güvenlik kavramı etrafında yapılacak tartışmalar, alternatif bir politika ya da özgürleştirici bir güvenlik tahayyül etmeye kapı aralayarak, hâlihazırda toplumda mevcut bulunan ekonomik eşitsizlik ya da yabancı düşmanlığı gibi sorunların çözümüne katkı sunabilir. Basu ve Nunes'in de altını çizdikleri gibi:

"güvenlikle ilgili fikirler, mümkün ve arzu edilen şeylerin sınırlarını tanımlayarak politik alanın şekillenmesine katkıda bulunur. Güvenlik, siyaseti şekillendiren politik bir olgudur. Bu nedenle güvenliğin 'siyasallaşması', güvenlik bilgisinin baskın düzenlemeleri desteklemedeki veya alternatif olarak bunları sorgulama ve dönüştürmedeki rolünün kabul edilmesini gerektirir." ${ }^{144}$

Başka bir ifadeyle, bu alanda gerçekleştirilebilecek özgürleştirici bir değişim ancak hem Türkiye'de yaşayan vatandaşların hem de Suriyeli mültecilerin yaşadıkları farklı güvensizlikleri dile getirerek mümkün olabilir. Bu bağlamda "sıradan siyasete" dönmek her zaman istenilen sonuçları vermeyebilir çünkü bazı durumlarda asıl güvensizlik "sıradan” siyasetin tam da içindedir. Örneğin, Booth’un da belirttiği gibi, “Eğer ırkçılık 'güvenlik-dışılaştırılırsa', kurumsallaşmış ırkçılığın sıradan siyaseti gelişebilir. Bu gibi durumlarda, mağdurun olağanüstü halini güç sahibinin normal politikasına dönüştürebilen güvenlik-dışılaştırma, güç sahiplerinin yararına olmaktadır." ${ }^{145}$

3, Hamburg, GIGA German Institute of Global and Area Studies, 2018. https://nbn-resolving.org/urn:nbn:de:0168ssoar-57809-3 (Erişim Tarihi 2 Mart 2020).

139 UNHCR, “Global Trends: Forced Displacement in 2018”.

140 Ken Booth, “Realities of Security: Editor's Introduction”, International Relations, Cilt 18, No 1, 2004, s. 7.

141 Booth, Theory of World Security, s. xii.

142 Ibid., s. 31.

143 Bilgin, "Güvenlik Çalışmalarında”, s. 84-85.

144 Basu ve Nunes, “Security as Emancipation”, s. 67.

145 Booth, Theory of World Security, s. 168. 
Aberystwyth ekolü "gerçek insanların gerçek yerlerdeki” güvensizliklerini analiz ederken "toplumdaki bazı grupları sistematik olarak savunmasız ve dezavantajl pozisyonlara koyan karmaşık sosyal ilişki ve yapıları"146 ele alarak başlar. Bu anlamda bireylerin ve grupların deneyimlediği güvensizlikleri tartışmadan önce bu güvensizlikleri ortaya çıkaran ulusal ve küresel düzeydeki ilişki ve yapıların yer aldığı bağlamı anlamak elzemdir. Türkiye'deki Suriyeli mültecilerin yaşadıkları güvensizlikler düşünüldügünde de hem mikro hem de makro düzeyde birbiriyle ilişkili çeşitli bağlamsal faktörden söz edilebilir.

Türkiye'deki Suriyeli mültecilerin deneyimledikleri güvensizlikleri anlamada bakılabilecek alanlardan ilki ulusal düzeyde devletin mülteciler konusunda izlediği politikalar ve bu politikaların işleyiş biçimleridir. Bu alanda son yıllarda gelişmeye başlayan ve devletin bu süreci nasıl yönettiğine odaklanan çalışmalara bakıldığında özellikle hukuki alandaki düzenleme ve eksikliklerin altının çizildiği görülebilir. ${ }^{147}$ Türkiye taraf olduğu 1951 tarihli mültecilerle ilişkili Cenevre Sözleşmesi’ne coğrafi sınırlama şerhi koyması nedeniyle ülkedeki Suriyeliler resmi olarak mülteci sayılmamaktadır. Bu bağlamda, Suriyeli mülteciler Türkiye’ye gelmeye başladıkları ilk yıllarda devlet tarafından "misafir" olarak tanımlanmışlar, ancak 2013 yılında yasalaştırılarak ertesi yıl yürürlüğe giren ve "iltica sürecini düzenleyen ve Türkiye'deki mültecilerin uluslararası korunmasını sağlayan ilk yasa”"148 olarak kabul edilen "Yabancılar ve Uluslararası Koruma Kanunu" ile Suriyeliler "geçici koruma” altında sayılmaya başlanmışlardır. Bu yasanın amacı "uluslararası insan hakları standartlarına göre mülteciler için daha iyi koruma sağlamak; eskiden büyük ölçüde polis tarafından koordine edilen göç/iltica yönetimini sivilleştirmek; yasal ve idari sığınma prosedürlerini standartlaştırmak ve sistematik hâle getirmektir”. ${ }^{149}$

Oluşturulan bu geçici koruma rejiminin olumlu yanı yetkili makamlara kayıt olmak şartıyla mültecilerin geri gönderilmemesi ilkesine (non-refoulement) bağlı olması ve mültecilerin eğitim, sağlık gibi temel sosyal hizmetlere erişiminin sağlanması gibi düzenlemeleri içermesidir. ${ }^{150} \mathrm{Bu}$ anlamda geri göndermeme ilkesine dayanan bu politika Birleşmiş Milletler, Avrupa Komisyonu (European Commission) gibi farklı uluslararası aktörler tarafından takdir toplamıştır. ${ }^{151}$ Öte yandan, bu geçici koruma rejiminin uygulamadaki eksiklerinden dolayı, bir sonraki bölümde detaylarıyla ele alınacağı üzere, mültecilerin birçok farklı güvensizlik deneyimlemesine de sebebiyet verdiği dile getirilmektedir.

Örneğin, Yıldız ve Uzgören'e göre geçici koruma rejimi hak temelli ve sürdürülebilir bir politikanın şekillenmesini sağlamaktan uzaktır. ${ }^{152}$ Çünkü, "kitlesel bir akın olması durumunda mültecilere derhal koruma sağlama amacıyla bir acil durum planı olarak tasarlanmış geçici koruma, devletlerin mülteci statüsü ve hakları verme konusundaki uluslararası yükümlülüklerinden kaçmalarına izin verme riski de

146 Basu ve Nunes, “Security as Emancipation”, s. 64.

147 Zeynep Kıvılcım, “Legal Violence Against Syrian Female Refugees in Turkey”, Feminist Legal Studies, Cilt 24, No 2, 2016, s. 193-214; Elif Sari ve Cemile Gizem Dincer, “Toward a New Asylum Regime in Turkey?”, Journal for Critical Migration and Border Regime Studies, Cilt 3, No 2, 2017, s. 59-79; Deniz Sert, "The Oxymoron of Perpetual Temporary Protection: Syrians in Turkey", Migraciones Internacionales, Cilt 8, No 4, 2016, s. 279-284; Ayselin Yıldız ve Elif Uzgören, "Limits to Temporary Protection: Noncamp Syrian Refugees in İzmir, Turkey”, Southeast European and Black Sea Studies, 2016, DOI: $10.1080 / 14683857.2016 .1165492$.

148 Sarı ve Dinçer, “Toward a New Asylum”, s. 64.

149 Ibid., s. 64.

150 Umut Korkut, "Pragmatism, Moral Responsibility or Policy Change: The Syrian Refugee Crisis and Selective Humanitarianism in the Turkish Refugee Regime”, Comparative Migration Studies, Cilt 4, No 2, 2016, s. 2.

151 Yildız ve Uzgören, "Limits to Temporary", s. 2.

152 Ibid., s. 2. 
taşımaktadır". ${ }^{153}$ Hak-temelli olmak yerine hizmet-temelli bir anlayışa dayanan bu rejim, örneğin, sosyal ve ekonomik hakları politik otoritenin keyfi kararlarına bırakmakta, mültecileri sömürüye açık bir hale getirmekte ve mültecilerin içindeki dezavantajlı grupları (yaşlılar, engelliler, çocuklar gibi) daha da kırılgan hale getirmektedir. ${ }^{154}$ Diğer bir deyişle, yasal bir mültecilik statüsünü tanımayan bu rejim mültecilerin sömürüldüğü pratiklere sebep olmakta ve yine bu rejimin "geçiciliği” mültecilerin eğitim ve sağllk hizmetlerine erişim, çalışma izni almadaki kısıtlar gibi bir dizi güvensizliği beraberinde getirmektedir. ${ }^{155}$

Yine Türkiye bağlamında altı çizilen bir diğer önemli faktör ise ülkedeki mülteci yönetimini şekillendiren ekonomik ilişki ağlarıdır. Örneğin, Belanger ve Saraçoğlu Türkiye'deki mülteci politikalarını anlamak için devletin izlediği politikalar ve sermaye/iş sahiplerinin çıkarları arasındaki örtüşmeyi analiz etmenin öneminin altını çizmektedirler. ${ }^{156}$ Yazarlara göre Suriyeli mülteciler konusundaki yasal düzenlemeler ve bu düzenlemelerin disipline edici etkisi, ülkedeki mevcut geçici koruma rejimi ve mültecilerin kayıt dışı sektörde oluşturduğu iş gücü konusunda devletin gösterdiği ad hoc müsamaha, sermayedarlar ve işverenler için "kolaylaştırıcı" bir işlev görmektedir. ${ }^{157} \mathrm{Bu}$ düzenleme ve uygulamalar neticesinde mültecilerin yasal çalışma imkânlarına erişmesi zorlaşmakta, mülteciler güvencesiz biçimlerde çalışmaya mecbur bırakılmakta ve bu durum farklı sektörlerde ücretlerin düşmesine neden olmaktadır. Özetle devlet ve sermayedarlar arasındaki uyum, daha fazla kâr edilebilmesi yolunda Suriyeli mültecileri (onlarla aynı emek piyasasında yer alan diğer işçilerle beraber toplu halde) sömürü düzeyinde çalışma koşullarına mahkûm bırakmaktadır. ${ }^{158}$

Türkiye'deki Suriyeli mültecilerin karşılaştıkları ve onlar için çeşitli güvensizlikler yaratan ulusal ölçekli faktörlerin yanı sıra, hem bu faktörlerin oluşmasına katkı yapan hem de bu faktörler tarafından şekillenen bölgesel ya da küresel düzeydeki ilişki ve yapıların da altını çizmek elzemdir. Küresel anlamda değinilmesi gereken faktörlerden biri neoliberal ekonomik yapılar ve bu yapıların doğurduğu ilişki biçimleridir. Ekonomi politik alanında çalışan araştırmacılara göre içinde yaşadığımız neoliberal ekonomik sistemin devam etmesinde "devlet-sermaye bağı” ın yaşamsal bir önemi vardır. ${ }^{159}$ Diğer bir deyişle, kapitalizm krizlerinin üstesinden gelmek için, "emeğin disiplin ve itaatini sağlamak için yeni teknikler" geliştiren devletlere ihtiyaç duymaktadır. ${ }^{160}$ Neoliberal ekonominin bir parçası olan Türkiye'de de, Suriyeli mültecilerin özellikle ekonomik sektörde yaşadıkları güvensizlikler bu yapısal faktörden ayrı düşünülemez. Bunun dışında değinilebilecek diğer makro faktör ise tüm dünyada ar$\tan$ mülteci ve genel olarak yabancı düşmanl ${ }_{\text {ğ }}{ }^{161}$ ve Suriyeli mülteciler özelinde bu durumla ilişkili olarak uluslararası toplumun bu mültecilere verdiği tepkilerdir. Bu son noktaya ilişkin araştırmacılar, örneğin, uluslararası toplumun gerek sınırlarını mültecilere açmaları anlamında gerekse mültecilere insani yardım sağlaması konusunda yeteri çabayı göstermediğini ifade etmektedirler. ${ }^{162}$ "Kapsamlı bir

153 Ibid., s. 5.

154 Ibid., s. 5.

155 Korkut, "Pragmatism”, s. 5-6; Sert, “The Oxymoron”, Kim Rygiel, Feyzi Baban ve Suzan Ilcan, “The Syrian Refugee Crisis: The EU-Turkey 'Deal' and Temporary Protection”, Global Social Policy, Cilt 16, No 3, 2016, s. 315-320.

156 Danièle Bélanger ve Cenk Saracoglu, “The Governance of Syrian Refugees in Turkey: The State-Capital Nexus and its Discontents", Mediterranean Politics, 2018, DOI:10.1080/13629395.2018.1549785.

157 Ibid., s. 2.

158 Ibid., s. 15.

159 Ibid., s. 1.

160 Ibid.

161 United Nations, "Racism, Xenophobia Increasing Globally, Experts Tell Third Committee, amid Calls for Laws to Combat Hate Speech, Concerns over Freedom of Expression”, 2016, https://www.un.org/press/en/2016/gashc4182. doc.htm (Erişim Tarihi 2 Mart 2020).

162 Yıldız ve Uzgören, "Limits to Temporary", s. 2. 
uluslararası yardım mekanizması ve yeniden yerleşim programının olmaması ve gelişmiş ülkeler tarafından kabul edilen az sayıda mülteci”, Suriyeli mültecilerin korunmasını Türkiye'nin de içinde olduğu Suriye'nin komşularına bırakılması sonucunu doğurmaktadır. ${ }^{163}$

Bölgesel bir faktör olarak ele alınabilecek konulardan birisi ise Suriyeli mülteciler konusunda Türkiye ve Avrupa Birliği arasında gelişen ilişkilerdir. Bu anlamda, literatürde göç kontrolünün "dışsallaştırılması” olarak bilinen ve AB’nin kendi sınırlarını düzensiz göçten korumak için "göç kontrol araçlarını ve kısıtlayıcı iltica politikalarını"164 üçüncü ülkelere aktarması olarak tarif edilebilecek politikanın altı çizilebilir. Avrupa Birliğinnin Türkiye’ye doğru dışsallaştırdığı mülteci ve göç politikaları ile birlikte Türkiye'nin "mültecileri - özellikle Suriyelileri - kendi sınırları içinde tutarak AB'nin dış sınırlarını korumaktan sorumlu bir tampon devlet haline geldiği” ifade edilmektedir. ${ }^{165}$ AB'nin izlediği bu politikayla birlikte özellikle 18 Mart 2016 yılında Türkiye ve Avrupa Birliği arasında varılan ve Türkiye’nin geri dönen düzensiz göçmenleri kabul etmesi karşllı̆ında Türkiye’deki Suriyeli mültecileri yeniden yerleştirilmek üzere Avrupa'ya gönderilmesi, Türkiye vatandaşlarına vize serbestliği gibi maddeleri içeren mutabakat ciddi bir eleştiri konusu olmuştur. ${ }^{166}$ Örneğin Uluslararası Af Örgütü anlaşmanın "Avrupa Birliği’nin küresel bir mülteci krizine sırt çevirme ve uluslararası yükümlülükleri bile isteye göz ardı etme kararlılığını gizleyemediğini” beyan etmiştir. ${ }^{167}$

\section{Güvenliğin Referans Nesneleri ve Aktörlerini Anlamak}

Yukarıda belirtildiği üzere eleştirel güvenlik çalışmalarının literatüre yaptığı en önemli katkılardan biri güvenliğin anlamını askeri konuların ötesinde genişletmeleridir. Aberystwyth ekolü de böylesi geniş bir güvenlik tanımından yola çıkmakta, fakat yukarıda da ele alınmış olan Kopenhag ya da Paris ekollerinden farklı olarak bu farklı güvensizliklerin birey ya da gruplar tarafından nasıl deneyimlendiğine odaklanmaktadır. Dolayısıyla, Aberystwyth ekolü güvenliği fakirlik, eğitim ve sağlık hizmetlerine erişmedeki kısıtlar gibi konulara referansla tanımlamakta ve bunu yaparken de sınıf ya da toplumsal cinsiyet temelli güvensizlikleri ele almaktadır. ${ }^{168}$ Türkiye'de hem Suriyeli mültecilerin hem de bu mülteci hareketinin kendileri hilafına yönetilmesinden çeşitli biçimlerde etkilenen Türkiyeli vatandaşların deneyimledikleri güvensizliklerin başında da bu konular gelmektedir. ${ }^{169}$

163 Ibid., s. 6.

164 Cavidan Soykan, “Access to International Protection-Border Issues in Turkey”, Dallal Stevens ve Maria O’Sullivan (der.), States, the Law and Access to Refugee Protection: Fortresses and Fairness. Oxford, Portland, Hart Publishing, 2017, s. 73.

165 Sarı ve Dinçer, “Toward a New Asylum”, s. 73.

166 Rygiel, Baban ve Ilcan, “The Syrian Refugee Crisis”.

167 Amnesty International, EU-Turkey Refugee Deal a Historic Blow to Rights”, 2016, https://www.amnesty.org/en/ latest/news/2016/03/eu-turkey-refugee-deal-a-historic-blow-to-rights/ (Erişim Tarihi 20 Mayıs 2020).

168 Basu ve Nunes, "Security as Emancipation”, s. 67.

169 Osman Bahadır Dinçer et al., “Turkey and Syrian Refugees: The Limits of Hospitality”, Kasım 2013, https://www. brookings.edu/wp-content/uploads/2016/06/Turkey-and-Syrian-Refugees_The-Limits-of-Hospitality-2014. pdf (Erişim Tarihi 2 Temmuz 2019); Kemal Kirişçi, "Syrian Refugees and Turkey’s Challenges: Going beyond Hospitality”, 12 Mayıs 2014, https://www.brookings.edu/research/syrian-refugees-and-turkeys-challengesgoingbeyond-hospitality/ (Erişim Tarihi 2 Temmuz 2019); Amnesty International, "Struggling to Survive: Refugees from Syria in Turkey”, 2014, https://www.amnestyusa.org/files/eur_440172014.pdf (Erişim Tarihi 2 Temmuz 2019); Kemal Kirişçi ve Elizabeth Ferris, "Not Likely to Go Home: Syrian Refugees and the Challenges to Turkey and the International Community”, Eylül 2015, https://www.brookings.edu/wp-content/uploads/2016/06/Turkey-PolicyPaper-web.pdf (Erişim Tarihi 2 Temmuz 2019); Doğuş Şimşek, “Anti-Syrian Racism in Turkey”, 27 Ocak 2015, https://www.opendemocracy.net/en/north-africa-west-asia/antisyrian-racism-in-turkey/ (Erişim tarihi 2 Temmuz 2019); Koca, "Syrian Refugees". 
Türkiye'deki Suriyeli mülteciler üzerine çalışan sivil toplum örgütleri ve akademisyenlerin belirttiği üzere mülteciler barınma, eğitim, sağlık hizmetleri ve yeterli gıdaya erişim, yasal iş imkanları, sağlıklı çalışma koşulları gibi en asgari düzeydeki ekonomik ve sosyal haklar alanında dahi zorluklarla karşılaşmaktadırlar. ${ }^{170}$ Örneğin, çalışma hayatı göz önüne alındığında mültecilerin mevcut yasalar ışığında yasal istihdam olanaklarından faydalanmalarının ya da çalışma izni almalarının oldukça zor olduğu belirtilmektedir. ${ }^{171} \mathrm{Bu}$ konuda yasal alanda yapılan çeşitli düzenlemeler mevcut olsa da mültecilerin genellikle kayıt dışı bir şekilde, kötü koşullar altında çalıştıııldıklarını ortaya koyan çeşitli araştırmalar mevcuttur. ${ }^{172} \mathrm{Bu}$ durum uzun çalışma saatleri, düşük ücretler, ya da sağlıklı çalışma koşullarının eksikliğinden kaynaklanan birçok güvensizliğe sebep olmaktadır. ${ }^{173}$ Özellikle tarım, tekstil ve inşaat gibi düşük vasıflı işgücü talebinin olduğu kayıt dışı sektörlerde çalışmak "Suriyeliler için farklı biçimlerde yoksulluk döngüsünü pekiştirmektedir”. ${ }^{174}$ Örneğin tarım alanında mevsimlik işçi olarak çalışan Suriyeli mülteciler hem olumsuz koşullarda çalışmakta hem de tarım arazilerinin yerleşimlerinin izole olmasından dolayı sağlık, eğitim ve diğer sosyal hizmetlere erişememektedir. ${ }^{175}$

Ekonomik güvensizliklerin yanı sıra, Türkiye'de artmakta olan bir yabancı düşmanlığı da gözlenmektedir. Şimşek bu yabancı düşmanlığının "Suriyeliler işlerimizi ve evlerimizi alıyorlar”, "Suriyeliler kültürümüze adapte olmuyorlar”, “Türkiye'deki suç oranları Suriyeliler yüzünden artıyor” gibi söylemlerle kendisini gösterdiğini ve göç karşıtı gösteri, hatta fiziksel saldırıların, ülkede artmakta olduğunu belirtmektedir. ${ }^{176} \mathrm{Bu}$ noktayı destekleyen bir bulgu KONDA araştırma şirketinin 2016 ve 2019 yıllarında yaptığı iki araştırmaya karşılaştırmalı bakıldığı takdirde görülebilir: Bu üç yıl zarfında Türkiye vatandaşlarının Suriyeli mültecilere bakış açılarında olumsuz yönde büyük değişimler olmuştur. ${ }^{177}$

Aberystwyth ekolünün de altını çizdiği üzere dünyanın farklı yerlerinde eşitsizlik ve adaletsizliklere sebep olan ve böylelikle toplumlarda bazı grupları dezavantajlı duruma getiren en önemli yapısal faktörlerden biri toplumsal cinsiyet hiyerarşileri ve ataerkilliktir. ${ }^{178} \mathrm{Bu}$ iki kavram bizlere farklı grupların karşılaştığı birbirinden farklı tehditleri anlamak için önemli ipuçları vermektedir. ${ }^{179} \mathrm{Bu}$ anlamda Suriyeli kadın mültecilerin, erkek mültecilerden farklı olarak deneyimledikleri farklı güvensizlikler olduğunu belirtmek gerekmektedir. Diğer bir deyişle, mültecilik statüsü ve toplumsal cinsiyet arasında bir keşisimsellik vardır ${ }^{180}$ ve Türkiye örneğinde bu keşisimsellik kadınların erkeklere göre

170 Amnesty International, “Struggling”; İçduygu ve Şimşek, "Syrian Refugees in Turkey”; Feyzi Baban, Suzan Ilcan ve Kim Rygiel, "Syrian Refugees in Turkey: Pathways to Precarity, Differential Inclusion, and Negotiated Citizenship Rights", Journal of Ethnic and Migration Studies, Cilt 43, Say1 1, s. 41-57.

171 Kirişçi, “Syrian Refugees”, s. 21.

172 Ahmet İçduygu ve Eleni Diker, “Labor Market Integration of Syrian Refugees in Turkey: From Refugees to Settlers”, The Journal of Migration Studies, Cilt 3, No 1, 2017, s. 12-35.

173 Amnesty International, "Struggling”.

174 İçduygu ve Diker, “Labor Market”, s. 24.

175 Ibid., s. 24-25.

176 Şimşek, “Anti-Syrian”.

177 KONDA, "Suriyeli Sığınmacılara Bakış”, 2016, https://konda.com.tr/tr/rapor/suriyeli-siginmacilara-bakis/ (Erişim tarihi 06 Mart 2020); “Suriyeli sığınmacılara bakış 3 yılda büyük oranda olumsuz yönde değişti”, Euronews, 29 Temmuz 2019, https://tr.euronews.com/2019/07/29/suriyeli-siginmacilara-bakis-3-yilda-buyuk-oranda-olumsuz-yondedegisti (Erişim Tarihi 06 Mart 2020).

178 Basu, "Security as Emancipation"; Booth, Theory of World Security, s. 22.

179 Basu ve Nunes, "Security as Emancipation”, s. 72.

180 Lena Knappert, Angela Kornau, Meltem Figengül, "Refugees' Exclusion at Work and the Intersection with Gender: Insights from the Turkish-Syrian Border”, Journal of Vocational Behavior, Cilt 105, No 1, 2018, s. 62-82. 
daha zor iş bulmaları, iş bulmaları durumunda eşit işe eşit ücret alamamaları, iş yerlerinde cinsel şiddete maruz kalmaları ve ev içi emeklerinin göz ardı edilmesi şeklinde tezahür etmektedir.

Yukarıda da ele alındığı gibi mültecilerin deneyimlediği güvensizlikleri ortaya çıkaran en önemli faktörlerden birisi hukuki alandaki düzenlemeler ve düzenlemelerin uygulanış biçimleri ile ilgilidir. $\mathrm{Bu}$ hukuki işleyişi toplumsal cinsiyet temelinde ele aldığı makalesinde Kıvılcım Türkiye'deki Suriyeli mülteci kadınların "hukuki şiddete” maruz kaldıklarını dile getirmektedir. ${ }^{181}$ Yazar hukuki şiddeti “yasalarla kodlanan veya güçlendirilen yapısal ve sembolik” bir şiddet biçimi olarak tanımlamakta, hukuki düzenlemelerin ayrımcılığı ve sosyal asimetrileri normalleştirip meşrulaştırmak suretiyle farklı şiddet biçimlerini yeniden ürettiğini belirtmektedir. Devlet her ne kadar bu şiddetin direkt uygulayıcısı olmasa da şiddet gören kadın mültecilerin yaşadıkları karşısında gerekli hukuki adımları atmamakta, böylece de farklı aktörler tarafından bu kadınlara uygulanan fiziksel, cinsel, ekonomik şiddetin cezasız kalmasına ve devam etmesine sebebiyet vermektedir. Burada altı çizilebilecek şiddet biçimlerinden bir tanesi birbiriyle iç içe geçmiş olan cinsel ve ekonomik şiddet biçimleridir. Kıvılcım’a göre "Göçmen kadınlar, Türkiye’nin derinleşen neoliberal yeniden yapılanma ve esnek işgücü piyasasının risklerine karşı en savunmasız gruplardan biridir”. ${ }^{182}$ Bu ekonomik kırılganlık ve bu kırılganlığın ürettiği fakirlik durumu kadın mültecilerin iş yerlerinde cinsel olarak sömürülmesine, kadınların ve kız çocuklarının zorla evlendirilmelerine, çokeşliliğe ve ev içi şiddete sebep olmaktadır.

Peki Türkiyeli vatandaşlar Suriyeli mültecilerin Türkiye'ye gelmesiyle oluşan dinamiklerden kaynaklanan ne gibi güvensizlikler deneyimlemektedirler? Bu soruya cevap vermek, yukarıda da detaylarıyla tartışıldığı üzere, Aberystwyth ekolü için oldukça önemlidir çünkü bu ekole göre özgürleştirici politikalar başkalarının pahasına, başkalarının özgürleşme hedeflerini imkânsız kılarak elde edilemez. ${ }^{183}$

Berti’nin belirttiği üzere ev sahibi ülkenin vatandaşlarının güvensizlikleri bu ülkenin "hâlihazırdaki sosyal, politik ve ekonomik" bağlamlarından ayrı düşünülemez. ${ }^{184}$ Örneğin, yukarıda da değinildiği üzere, Türkiye neoliberal ekonomik sistemde hareket eden bir aktör olarak bu sistemin ürettiği çeşitli ekonomik problemleri deneyimleyen bir ülkedir. OECD verilerine göre Türkiye gelir eşitsizliğinde, yoksulluk oranında ve işsizlikte öne çıan ülkelerden biridir. ${ }^{185}$ Öyle ki bu ekonomik problemler ve diğer sosyal ve politik sorunlar Türkiye'yi göçmen ve mülteci üreten bir ülke haline getirmektedir. ${ }^{186}$ Burada özellikle altı çizilmesi gereken nokta şudur: Türkiye'nin bu tipteki yapısal sorunları, Suriyeli mültecilerin güvensizliklerine neden olurken, eş zamanlı olarak kendi vatandaşlarının da güvensizlikleşmesi sonucunu doğurmaktadır. Diğer bir deyişle, aşağıda tartışılacak güvensizliklerin sebebi Suriyeli mülteciler değildir; onların ekonomiye katılımını düzenleyen hukuki ve politik pratiklerdir.

Bu bağlamda Türkiye'deki insanların deneyimledikleri temel güvensizlik de ekonomi temellidir. Suriyeli mültecilerin Türkiye'nin iş gücü piyasasına olan etkileri konusunda farklı bulgu-

181 Kivilcım, "Legal Violence".

182 Ibid., s. 205.

183 Booth, Theory of World Security, s.113.

184 Benedetta Berti, “The Syrian Refugee Crisis: Regional and Human Security Implications”, Strategic Assessment, Cilt 17, No 4, 2015, s. 41-53.

185 OECD, Turkey, https://data.oecd.org/turkey.htm (Erişim Tarihi 12 Mart 2020).

186 İbrahim Sirkeci, “Turkey's Refugees, Syrians, and Refugees from Turkey: A Country of Insecurity”, Migration Letters, Cilt 14, No 1, 2017, s. 127- 144. 
lar vardır. Bir yandan mültecilerin Türkiye'deki en büyük yabancı yatırımcı grubu oluşturduğu ve özellikle bazı şehirlerde olumlu ekonomik etkilere sebep oldukları belirtilmektedir. ${ }^{187}$ Öte yandan, Suriyeli mültecilerin (kayıtlı sektörler göz önüne alındığında) yerli işgücünün maaş ya da iş olanaklarında olumsuz bir etki yaratmadıkları belirtilmektedir. ${ }^{188}$ Fakat Türkiye Cumhuriyeti vatandaşları için, Suriyeli mültecilerin çoğunlukla çalıştıkları, düşük vasıflı kayıt dışı iş gücü alanında çeşitli ekonomik güvensizlikler oluştuğunu gözlemlemek mümkündür. Suriyeli mültecilerin bu alanda daha az ücrete çalışmayı kabul etmek zorunda kalmaları işverenlerin yerli işçiler yerine Suriyelileri tercih etmesine sebep olmakta, dolayısıyla bu durum maaş ve iş olanakları üzerinde olumsuz bir etki yaratmaktadır. ${ }^{199} \mathrm{Bu}$ dinamik diğer düşük vasıflı iş gücünü oluşturan vatandaşlar ile mülteciler arasında bir gerilime sebep olmaktadır. ${ }^{190} \mathrm{Bu}$ duruma bir örnek olarak halihazırda "emeğin değersiz ve güvencesiz olduğu" ve "derinleşen sınıf içi çatışma”nın gözlemlenebileceği mevsimlik tarım işçiliği verilebilir. ${ }^{191}$ Suriyeli mültecilerin Türkiye’ye gelmesinden önce mevsimlik tarımsal üretimin dayanak noktası olan Kürt vatandaşlarıyla daha düşük ücretleri kabul etmek zorunda kaldıkları için bu üretimde daha çok tercih edilmeye başlayan Suriyeli mülteciler arasında oluşan gerginlik bu durumu örneklemektedir. ${ }^{192}$ Burada altı çizilmesi gereken bir diğer nokta ise bu ortaklaşa deneyimlenen sömürünün her zaman gerginlik ve çatışma yaratmadı̆̆ lerde Türk, Kürt ve Suriyeli işçilerin içinde bulundukları ekonomik koşulları dayanışma içinde, birlikte dile getirdikleridir. ${ }^{193}$

Türkiye'deki vatandaşların ve Suriyeli mültecilerin deneyimledikleri güvensizlikler değinildikten sonra sorulması gereken bir başka soru da Aberystwyth ekolünün bu güvensizliklerin tespit edilip aşılması sürecindeki aktörleri düşünmek için bize ne gibi ipuçları verdiği ile ilgilidir. Yukarıda da tartışıldığı üzere bu ekole göre bireylerin yaşadıkları farklı güvensizlikleri aşmada yerel, ulusal ya da küresel alanda örgütlenmiş sivil toplum aktörlerinin önemli bir yeri vardır. ${ }^{194}$ Göç ve mültecilik alanlarının düzenlenmesi konusunda da (her ne kadar devletlerin bu alandaki baskın rolleri devam etse de) yerel, ulusal ve uluslararası sivil toplum kuruluşlarının (STK), ağ tipi örgütlenmelerin ve uluslararası örgütlerin önemleri artmaktadır. ${ }^{195}$ Türkiye'deki Suriyeli mülteciler düşünüldüğünde de benzer bir dinamik gözlemlemek mümkündür: uluslararası örgütler ve devlet dışı aktörler Türkiye'deki mültecilerin karşılaştığı çok çeşitli güvensizliklerle mücadele etmede, "hizmet sunumu" ya da "hak savunuculuğu"196 gibi çalışmalar yapmak suretiyle önemli roller ve görevler üstlenmektedirler. ${ }^{197}$

187 İçduygu ve Diker, “Labor Market”, s. 27.

188 Ibid., s. 28-29.

189 Ibid.

190 Ibid., s. 23.

191 Hayata Destek Derneği, “Mevsimlik Gezici Tarım İşçiliği 2014: Araştırma Raporu”, 2014, https://www.hayatadestek. org/wp-content/uploads/2014/12/mevsimlik-gezici-tarim-isciligi-2014-arastirma-raporu.pdf (Erişim Tarihi 3 Mart 2020).

192 İçduygu ve Diker, “Labor Market”, s. 25. Ayrıca bknz. Baban, Ilcan ve Rygiel, “Syrian Refugees”, s.12.

193 Bir örnek için bkz. "Adana'da saya işçileri hakları için ayakta”, https://www.evrensel.net/haber/331581/adanada-sayaiscileri-haklari-icin-ayakta (Erişim Tarihi 20 Mart 2020).

194 Basu ve Nunes, “Security as Emancipation”, s. 73.

195 Fulya Memişoğlu ve Aslı Ilgit, "Syrian Refugees in Turkey: Multifaceted Challenges, Diverse Players, and Ambiguous Policies”, Mediterranean Politics, DOI:10.1080/13629395.2016.1189479, 2016, s. 6.

196 Nazlı Şenses, “Göçmen Odaklı Sivil Toplum Oluşumları: Değişen Eylemler ve Siyasetler”, Alternatif Politika, Cilt 20, No 1, 2020, s. 50-78.

197 Ibid. 
Uluslararası örgütler göz önüne alındığında bilhassa Birleşmiş Milletler bünyesindeki Birleşmiş Milletler Mülteciler Yüksek Komiserliği (UNHCR), Birleşmiş Milletler Dünya Gıda Programı (WFP), Birleşmiş Milletler Çocuklara Yardım Fonu (UNICEF), Dünya Sağlık Örgütü (WHO) gibi örgütlerin mültecilerin deneyimlediği güvensizliklerin giderilmesinde hem resmi makamlarla hem de sivil toplum örgütleriyle koordineli çalışmalar yürüterek önemli ilerlemeler kaydettikleri belirtilmektedir. ${ }^{198}$ Örneğin, İçduygu ve Diker’in aktardığına göre, özellikle mültecilerin karşılaştıkları ekonomik tehditlerin ortadan kalkmasına yönelik olarak UNHCR; Hayata Destek Vakfı, Danimarka Mülteci Konseyi, Yuva Derneği, Uluslararası Mavi Hilal İnsani Yardım ve Kalkınma Vakfı gibi diğer sivil toplum örgütleriyle işbirliği yapmakta ve bu alanda kamuoyunu bilinçlendirme, mesleki becerilerin artırılması için çeşitli kurslar açma ve ulusal ve yerel düzeylerde kurumsal kapasitelerin artırılması gibi konularda faaliyetler yürütmektedir. ${ }^{199}$

Türkiye'deki Suriyeli mültecileri etkileyen sorunların ele alınmasında diğer bir önemli aktör STK'lardır. Bu kuruluşlar “kayıt, yasal yardım ve geri dönüş, eğitim, dil ve istihdam ve geçim” alanlarında faaliyet göstermekte ve buralarda hem mültecilere destek olmakta hem de devletin ve uluslararası örgütlerin bıraktıkları boşlukları doldurmaktadırlar. ${ }^{200}$ Memişoğlu ve İlgin bu STK'lara örnek olarak bünyesinde farklı sivil toplum örgütlerini barındıran "Mülteci Hakları Koordinasyonu”nu vermektedir. ${ }^{201}$ Yazarlara göre bu platform hukuki düzenlemelere danışmanlık sağlama, göç ve iltica konularıyla ilgili raporlar yayınlama, mülteciler konusunda kamusal farkındalığı arttırma, mültecilerin eğitim ya da sağlık hizmetlerine erişimlerindeki eksiklerin giderilmesi gibi farklı alanlarda çalışmaktadır. ${ }^{202}$ Burada altı çizilmesi gereken bir diğer önemli husus Suriyeliler tarafından kurulan sivil toplum örgütlerinin varlığı ve faaliyetleridir. İçduygu ve Diker'in belirttiğine göre Rızık Derneği ve Maharet Kapasite Geliştirme Derneği gibi sivil toplum örgütleri Suriyeli mültecilerin iş becerilerini geliştirme ve işgücüne katılımlarını arttırmak için önemli faaliyetler yürütmektedir. ${ }^{203} \mathrm{Bu}$ alanda son olarak altı çizilebilecek diğer bir aktör ise örgütlenme biçimleriyle STK'lardan ayrılan, genellikle aktivist ya da gönüllülerin oluşturduğu "inisiyatif, platform veya ağ tipi örgütlenmeler" dir. ${ }^{204} \mathrm{Bu}$ tip örgütlenmelere örnek olarak “Göçmen Dayanışma Ağı, Mülteciyim Hemşerim, Birlikte Yaşamak İstiyoruz İnisiyatifi” verilebilir. $^{205}$

\section{Sonuç}

$\mathrm{Bu}$ makale göç-güvenlik bağlantısı çalışılırken literatürde görece daha az ele alınmış bir eleştirel güvenlik yaklaşımı olan Aberystwyth ekolünün önerdiği çerçevenin bu bağlantıyı anlamada sunduğu katkıları Türkiye'deki Suriyeli mültecilerin durumuna odaklanarak irdelemeyi amaçlamıştır. Makale bunu yaparken öncelikle literatürde göç ve güvenlik ilişkisi anlamında daha çok yer bulmuş iki eleştirel güvenlik ekolü olan Kopenhag ve Paris ekollerinin kuramsal ve ampirik çalışmalarını incelemiştir. Bu

198 Ibid., s. 14-15.

199 İçduygu ve Diker, “Labor Market”, s. 30.

200 Bülent Aras ve Yasin Duman, "I/NGOs' Assistance to Syrian Refugees in Turkey: Opportunities and Challenges, Journal of Balkan and Near Eastern Studies, Cilt 21, No 4, 2019, s. 478-491.

201 Memişoğlu ve Ilgit, “Syrian Refugees”, s. 14.

202 Ibid.

203 İçduygu ve Diker, “Labor Market”, s. 31.

204 Şenses, “Göçmen Odaklı”, s. 68.

205 Ibid., s. 67. 
ekollerin daha çok güvenlikleştirme ve güvenliksizleştirme süreçlerine ve bu süreçleri şekillendiren politik, teknolojik ya da bürokratik güç sahibi aktörlere odaklandıkları, bunu yaparken çoğunlukla sıradan insanların deneyimledikleri güvensizlikleri göz ardı ettikleri vurgulanmıştır. Aynı zamanda bu iki ekolün kuramsal argümanlarının daha çok merkezi bağlamlardaki deneyimlere dayandırıldığı, bu nedenle merkez dışı bağlamlardaki güvensizlikleri anlamada kısıtları olduğu dile getirilmiştir.

Makale daha sonra Aberystwyth ekolünün önerdiği çerçevenin bu belirtilen kısıtların ötesine nasıl geçtiğini irdelemiştir. Makalede bu ekolün dünyanın farklı yerlerinde göçün güvenlik ile belli bir biçimde ilişkilendirilmesinin sebep olduğu sorunları aşmada diğer iki ekole göre bizlere daha çok yardımcı olabileceği ifade edilmiştir. Bunun nedeni olarak da Aberystwyth ekolünün göçün güvenlik-dışılaştırılmasından ziyade güvenliğin siyasiliğini ortaya koyması, böylelikle bireylerin yaşadıkları güvensizlikleri ortaya çıkarıp bu güvensizliklere özgürleşme perspektifinden yaklaşarak çözümler önerebilmesi gösterilmiştir. Bu çerçeveden yola çıkan makale bunun ilk adımı olarak güvenliğin referans nesnesi olarak bireyleri almak gerektiğini, diğer bir deyişle göç-güvenlik tartışmasında "kimin güvenliği?" sorusuna "göçmenler ve ev sahibi toplumlardaki vatandaşların güvenliği” cevabını vermiştir. İkinci olarak makale, güvenliğin aktörlerine dair düşünürken, her ne kadar bu alanda devletlerin baskın rolleri yadsınamaz olsa da devlet dışı aktörlerin öneminin altını çizmiş ve göç alanında arzu edilen değişimi gerçekleştirebilecek aktörler olarak uluslararası örgütler, sivil toplum kuruluşları ve aşağıdan gerçekleşen dayanışma pratiklerinin rollerine dikkat çekmiştir. Makale ayrıca Aberystwyth ekolünün somut durumlarda yerel aktörlerin deneyimlerini dikkate alması nedeniyle Güney-Güney göçünü ve merkez dışı bağlamları anlamada önemli katkılar sunduğunu vurgulamıştır.

Makale bu kuramsal tartışmayı örneklendirmek için merkez dışı bir bağlam olan Türkiye’ye ve bu ülkedeki Suriyeli mültecilere eğilmiştir. Makale hem Suriyeli mültecilerin hem de Türkiye'deki vatandaşların deneyimledikleri tehditlere odaklanmış ve bu alanda özgürleştirici politikaların çerçevesinin bu iki grubun yaşadıkları güvensizlikler düşünülerek çizilebileceğini belirtmiştir. Makale ayrıca bu politikaların şekillenmesinde devlet dışı aktörlerin rollerinin öneminin altını çizmiştir. Sonuç olarak bu makale Türkiye'deki Suriyeli mülteciler olgusunu bir güvenlik konusu olmaktan çıkarmak yerine, bu konuyu çevreleyen tartışmalarda güvenliğin siyasiliğinin vurgulanması gerektiğini ve bu vurgunun merkezinde de hem Suriyeli mültecilerin hem de Türkiye'deki vatandaşların deneyimlediği güvensizliklerin yer alması gerektiğini savunmuştur. 